\title{
ESCLAVITUD Y DEPENDENCIA PERSONAL EN EL PAÍS ASTURLEONÉS (SIGLOS IX-XIII)
}

\author{
Raúl GonZÁlez GonZÁlez ${ }^{1}$ \\ Universidad de Oviedo
}

\begin{abstract}
Resumen
El artículo propone una indagación reflexiva en torno a la esclavitud y las formas de dependencia personal en Asturias y León durante la Alta y la Plena Edad Media. Tras algunas precisiones de tipo terminológico y conceptual (con especial atención a los indicios que proporciona la lengua romance), se ofrece un análisis de la naturaleza de dichas relaciones de explotación y de su papel dentro de la economía señorial de la época, para finalizar con un repaso a su proceso de declive.
\end{abstract}

\section{Palabras clave}

Esclavitud; Servidumbre; Señorío; Historia social; Reino de León.

\begin{abstract}
This paper proposes a reflective investigation on slavery and the forms of personal dependency in Asturias and Leon during the Early and High Middle Ages. After some terminological and conceptual clarifications (with special attention to the clues provided by the Romance language), an analysis of the nature of these relations of exploitation and of their role within the manorial economy of the time is offered. To conclude, we have taken a look at their process of decline.
\end{abstract}

\section{Keywords}

Slavery; Servitude; Manor; Social History; Kingdom of Leon.

\section{Résumée}

L'article propose une réflexion sur l'esclavage et les formes de dépendance personnelle dans les Asturies et le León pendant le haut Moyen Âge et le Moyen Âge central. Après quelques précisions terminologiques et conceptuelles (avec une attention particulière aux indices fournis par la langue romane), on analyse la nature de ces relations d'exploitation et de leur rôle dans l'économie seigneuriale du temps, puis, pour finir, on jette un regard sur leur processus de déclin.

\section{Mots-clef}

Esclavage; Servitude; Seigneurie; Histoire sociale; Royaume de Léon.

1 Correo electrónico: raull@telecable.es. 


\title{
1. Introducción ${ }^{2}$
}

\subsection{Algunos fetiches terminológicos}

\begin{abstract}
Al igual que otras zonas del Occidente post-romano, el país asturleonés ${ }^{3}$ conoció en la Alta Edad Media una forma de explotación social especialmente dura, heredera sin
\end{abstract}

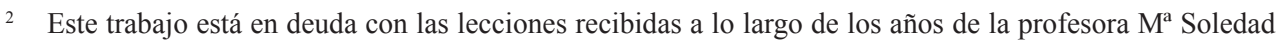
Beltrán Suárez, de la Universidad de Oviedo, quien despertó mi interés por las formas de dependencia social en la Edad Media ya en el primer año de la licenciatura en Historia durante aquel lejano curso 2004-2005 y lleva haciéndome reflexionar sobre ellas desde entonces. Abreviaturas utilizadas: Belmonte $=$ Antonio C. Floriano Cumbreño, Colección diplomática del monasterio de Belmonte, ed. Instituto de Estudios Asturianos, Oviedo, 1960; CCA = Gregoria Cavero Domínguez, Encarnación Martín LóPez y Santiago Domínguez SÁnchez, Colección documental de la catedral de Astorga, 3 vols., ed. Centro de Estudios e Investigación "San Isidoro", León, 1999-2000; CCL = V.V.A.A., Colección documental del Archivo de la Catedral de León, 13 vols. relativos a cronología medieval, ed. Centro de Estudios e Investigación "San Isidoro", León, 1987-2002; CCO = Santos García LARragueta, Colección de documentos de la catedral de Oviedo, ed. Instituto de Estudios Asturianos, Oviedo, 1962; Eslonza = José Manuel RuIz AsEncio e Irene Ruiz Albi, Colección documental del monasterio de San Pedro de Eslonza, vol. I (912-1300), ed. Centro de Estudios e Investigación "San Isidoro", León, 2007; Espinareda = Ma Jesús JimÉnEz SuÁrEz, Colección documental del monasterio de San Andrés de Espinareda (1043-1428), ed. Centro de Estudios e Investigación "San Isidoro", León, 2005; Gambra = Andrés Gambra, Alfonso VI. Cancillería, curia e imperio, vol. II: Colección diplomática, ed. Centro de Estudios e Investigación "San Isidoro", León, 1998; Gradefes = Taurino Burón Castro, Colección documental del monasterio de Gradefes, vol. I (1054-1299), ed. Centro de Estudios e Investigación "San Isidoro", León, 1998; Inscripciones = Francisco DiEGo SANTOS, Inscripciones medievales de Asturias, ed. Gobierno del Principado de Asturias, Oviedo, 1994; LTO = M ${ }^{\mathrm{a}}$ Josefa SAnz FuEntes et alii, Liber Testamentorum Ecclesiae Ovetensis, ed. M. Moleiro, Barcelona, 1995; Obona $=\mathrm{M}^{\mathrm{a}}$ Josefa Sanz Fuentes, "Documentación medieval del monasterio de Santa María de Obona en el Archivo Histórico Diocesano de Oviedo", Asturiensia Medievalia, 8 (1995-1996), pp. 291-339; Orixinales = Andrea M. Miranda Duque, Documentos orixinales de los sieglos $I X-X$ de los archivos del monesteriu de San Pelayo y de la catedral d'Uviéu, estudiu llingüísticu de Xosé Lluis García Arias, ed. Academia de la Llingua Asturiana, Uviéu, 2011; Otero = José Antonio FernÁndez Flórez y Marta Herrero de la Fuente, Colección documental del monasterio de Santa María de Otero de las Dueñas, 2 vols., ed. Centro de Estudios e Investigación "San Isidoro", León, 1999-2005; RC = Alfonso García Leal, El Registro de Corias, ed. Real Instituto de Estudios Asturianos, Oviedo, 2000; Sahagún = V.V.A.A., Colección diplomática del monasterio de Sahagún, 7 vols., ed. Centro de Estudios e Investigación "San Isidoro", León, 1976-1997; ReglaCol = Elena E. Rodríguez Díaz, El libro de la «Regla Colorada» de la catedral de Oviedo. Estudio y edición, ed. Real Instituto de Estudios Asturianos, Oviedo, 1995; Samos = Manuel LuCAs ÁlvarEz, El Tumbo de San Julián de Samos (Siglos VIII-XII). Estudio introductorio. Edición diplomática. Apéndices e indices, ed. Caixa Galicia, Santiago de Compostela, 1986; SMV=Andrés MArTínez VeGA, El monasterio de Santa María de la Vega, vol. I: Colección diplomática, ed. Instituto de Estudios Asturianos, Oviedo, 1991; $\mathrm{SVO}=$ Pedro Floriano Llorente, Colección diplomática del monasterio de San Vicente de Oviedo. Estudio y transcripción, ed. Instituto de Estudios Asturianos, Oviedo, 1968; SVOAdd = M Josefa SANZ FuEnTES, "Más documentos del monasterio de San Vicente anteriores al 1200", Asturiensia Medievalia, 5 (1986), pp. 89-109; TA = Manuel Lucas Álvarez, La documentación del Tumbo A de la catedral de Santiago de Compostela. Estudio y edición, ed. Centro de Estudios e Investigación "San Isidoro", León, 1997; TVM = Augusto Quintana Prieto, Tumbo Viejo de San Pedro de Montes, ed. Centro de Estudios e Investigación "San Isidoro", León, 1971.

3 A tenor de los comentarios de ambos evaluadores del artículo, parece necesario detenerse a justificar el término. Pese a su pretendida falta de tradición en los estudios de temática medieval, en realidad ya Juan Ignacio Ruiz de la Peña, maestro de medievalistas, utilizaba asiduamente en sus trabajos términos como 
duda del esclavismo antiguo. Para designarla, los medievalistas se han mostrado tradicionalmente reticentes a utilizar la etiqueta de "esclavitud", que prefieren reservar para las sociedades de la Antigüedad ${ }^{5}$.

Ahora bien, si la pregunta es si en el reino de León hubo un sistema esclavista idéntico al de la época clásica, la respuesta ha de ser evidentemente negativa, pero si tratamos de alejarnos de ese etnocentrismo que convierte al mundo grecolatino en la medida de todas las cosas y adoptamos una perspectiva más amplia ${ }^{6}$, yo estaría muy dispuesto a

\footnotetext{
"país astur" o "traspaís leonés" que en conjunto abarcan esa misma realidad, y la romanística ha consolidado desde hace mucho tiempo la noción de "dominio asturleonés" como unidad lingüística. Con la noción de "país asturleonés" aludo pues a un ámbito geográfico conformado por Asturias y lo que será conocido en época plenomedieval como la "Tierra de León" (vid. infra nota 113), aunque a lo largo del trabajo aparezca también alguna mención ocasional al Bierzo.

4 Tal y como describe aguda y certeramente Carl I. Hammer, A Large-Scale Slave Society of the Early Middle Ages: Slaves and their Families in Early Medieval Bavaria, ed. Ashgate, Aldershot, 2002, pp. 4-5: "Historians are often forced to deploy verbal gymnastics and circumlocutions in their efforts to demonstrate that, whatever they find in the records of early medieval Europe, it is not really slavery. And a language of euphemisms has been invented or appropriated to advance this effort. Consider the mellowing effect of 'serf' or 'servant' or 'bondsman' or 'handmaiden' or the desire to leave the terms 'servus', 'ancilla' and 'mancipium' untranslated, thereby neutralizing them as termini technici (...) it is essential to recognize that slavery itself was (and still is) a multifaceted and varied institution, conditioned by the specifics of historical period, geography and culture, and that the peculiarities and variations which often are advanced to exempt the early medieval examples all fall comfortably within the range well known to anthropologists, sociologists and historians of other periods and places". En la historiografía sobre el reino asturleonés lo tradicional ha sido hablar de siervos, al menos hasta que el fin del paradigma institucionalista supuso el abandono de la consideración de los dependientes personales como objeto merecedor de estudios específicos: lo importante a partir de entonces fue hablar de los campesinos y las comunidades locales como grupos explotados en conjunto por el feudalismo, sin entrar en distinciones consideradas como meros legalismos superficiales o anecdóticos. Como consecuencia de este abandono historiográfico, el trabajo de referencia sobre el tema sigue siendo Claudio Sánchez-Albornoz, "Los siervos en el noroeste hispano hace un milenio", Viejos y nuevos estudios sobre las instituciones medievales españolas, tomo III: Últimos estudios, ed. Espasa-Calpe, Madrid, 1980, pp. 1523-1611; publicado originalmente en Cuadernos de Historia de España, 61-62 (1977), pp. 5-95.

5 La principal excepción la constituyen los autores de la corriente historiográfica que Dominique Barthélemy, uno de sus principales detractores, ha dado en llamar "mutacionismo". De entre ellos, el texto de referencia sigue siendo Pierre BonNassie, "Supervivencia y extinción del régimen esclavista en el Occidente de la Alta Edad Media (siglos IV-XI)", Del esclavismo al feudalismo en Europa occidental, ed. Crítica, Barcelona, 1993, pp. 13-75. Se ofrece un lúcido balance historiográfico sobre la cuestión en Juan José LaRREA, "Esclavitud y servidumbre en el debate sobre la mutación feudal", Historiar. Revista Trimestral de Historia, 4 (2000), pp. 52-65 [quede constancia de mi gratitud al autor, quien hace ya años respondió con gentileza al correo electrónico de un completo desconocido y me envió una copia de este trabajo].

6 Carl I. Hammer, A Large-Scale Slave Society..., p. 5: "Bloch's model incorporates an overly restrictive view of slavery by equating it exclusively with a single historical form: the large-scale plantation slavery which emerged in Republican and early modern Imperial Rome as a result of the immense influx of slaves from foreign expansion and which is described in the contemporary agronomist writers such as Cato and Varro. On the contrary, it is essential to recognize that slavery itself was (and still is) a multifaceted and varied institution, conditioned by the specifics of historical period, geography and culture, and that the peculiarities and variations which often are advanced to exempt the early medieval examples all fall comfortably within the range well known to anthropologists, sociologists and historians of other periods and places".
} 
designar como esclavos a unos hombres y mujeres que, según registran inequívocamente los documentos medievales, eran desplazados a voluntad por sus amos, vendidos, entregados en arras o donados a instituciones eclesiásticas, con o sin tierras. Incluso contamos con algún raro ejemplo de cartas de manumisión, aunque es probable que la mayoría se refieran a esclavos domésticos.

Una solución cómoda - y con mucho arraigo en el medievalismo hispano- podría ser la de designar a esta esclavitud altomedieval como "servidumbre" o "servidumbre personal", de no ser porque eso podría generar problemas aún mayores. Se confundiría, en primer lugar, con los siervos personales de época posterior, lo cual no sería en realidad demasiado grave si tenemos en cuenta que éstos no son más que la forma evolucionada de los dependientes personales de la Alta Edad $\mathrm{Media}^{7}$. Pero sobre todo ha resultado historiográficamente catastrófica la confusión de los esclavos altomedievales con las formas de dependencia vinculadas a la tierra o la jurisdicción, de origen y naturaleza muy diferentes, que se generalizaron a partir del siglo XI y pervivieron con mejor o peor fortuna en las diferentes regiones europeas como símbolo por antonomasia del "régimen feudal" hasta la implantación del liberalismo. Es precisamente este Idealtypus de campesinos vasallos, sujetos a la justicia señorial, agobiados por exacciones de lo más diverso e idealmente "atados a la gleba" la que se ha consolidado en el vocabulario

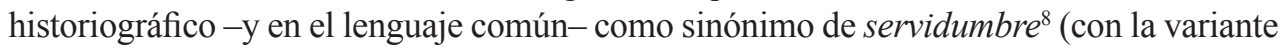

\footnotetext{
En el noroeste peninsular estos siervos personales no parecen haber pervivido más allá de la primera mitad del siglo XIII (aunque el problema de su desaparición nunca ha sido estudiado con detalle), pero sí jugaron un papel importante en otras zonas de la Europa bajomedieval. El principal estudioso del fenómeno fue Marc Bloch, cuya faceta como historiador de la servidumbre -tema recurrente a lo largo de su investigación y al que dedicó su tesis doctoral- es una de las menos reconocidas dentro de las clásicas aproximaciones hagiográficas que han venido enmascarando su obra. Y sin embargo, sus trabajos sobre la cuestión constituyen posiblemente algunas de las aportaciones de mayor calidad de toda su producción: en ellos muestra el alcance de su finura crítica, su erudición (en el mejor sentido del término) y su capacidad para ofrecer análisis complejos que anteponen las interpretaciones dinámicas a los esquematismos. Vid. su fundamental artículo Marc BLOCH, "Liberté et servitude personnelles au Moyen-Âge, particulièrement en France. Contribution à un étude des classes", Anuario de Historia del Derecho Español, 10 (1933), pp. 19-115 (fruto por cierto de una conferencia impartida en 1932 en la Semana de Historia del Derecho de Madrid, cuando el medievalismo español aún estaba en conexión con la investigación europea coetánea); así como los textos reunidos en Marc Bloch, Reyes y siervos y otros escritos sobre la servidumbre, ed. Universidad de Granada - Universitat de València, Granada, 2006, con un interesante "Posfacio" de Dominique BARTHÉLÉMY (pp. 413-442) que comienza con una afirmación bien significativa: "El libro y los artículos que componen esta obra deberían ser leídos en todas las universidades, en la clase de metodología histórica". Además de las aportaciones del viejo maestro, cabe reseñar la reciente publicación de un estudio de amplio aliento cronológico sobre las formas de dependencia servil en el antiguo reino de Borgoña: Nicolas CARRIER, Les usages de la servitude. Seigneurs et paysans dans le royaume de Bourgogne ( $V I^{e}-X V^{e}$ siècle), ed. PUPS, Paris, 2012.

8 Ya Marc Bцосн, "Liberté et servitude personnelles...", p. 51, calificaba esta tendencia de "habitude médiocrement heureuse". Para el noroeste peninsular apenas existen estudios recientes sobre las formas de dependencia plenomedievales, por lo que conservan toda su vigencia trabajos clásicos como Nilda Guglielmi, "La dependencia del campesinado no-propietario (León y Castilla - Francia, siglos XIXIII)", Anales de Historia Antigua y Medieval, 13 (1967), pp. 95-187; Raquel Номет, "Los collazos en Castilla (siglos X-XIV)", Cuadernos de Historia de España, 59-60 (1976), pp. 105-219; o José Luis Martín, "Campesinos vasallos de la iglesia de Zamora", Estudis d'Història Agrària, 1 (1978), pp. 85-
} 
más amable de quien equipara meramente siervo a colono). Por todo ello no parece aconsejable contribuir a seguir oscureciendo el análisis aplicando también el término a los dependientes personales de la Alta Edad Media. Sobre todo porque no contamos con un doblete léxico, al estilo del francés servitude-servage o el inglés servitude-serfdom, que permita establecer al menos una cierta discriminación terminológica.

\subsection{La conexión romance}

Tampoco merece la pena detenerse demasiado en la evolución del léxico servil de la época como si fuese un indicador fiable de los procesos de cambio social. Sobre todo si olvidamos un hecho fundamental: las gentes de la Alta Edad Media no hablaban ni pensaban cotidianamente en latín. A la hora de redactar sus documentos utilizaban una lengua heredada que ya no era la suya, y aunque su escritura estaba muy condicionada

97. Prácticamente con la única excepción de Pascual Martínez Sopena (vid. por ejemplo su sugerente "Liberté et servitude paysanne en Castille et León, du X ${ }^{\mathrm{e}}$ au XIII" siècle", Écritures de l'espace social. Mélanges d'histoire médiévale offerts à Monique Bourin, Didier Boisseuil et alii (eds.), ed. Publications de la Sorbonne, Paris, 2010, pp. 595-612) [agradezco profundamente al autor que ya hace años atendiese la petición de un desconocido y me enviase amablemente una separata de este trabajo, al que yo no tenía acceso] y de algunos trabajos sobre Galicia (singularmente Marcos Fernández Ferreiro, Servos e escravos altomedievais no noreste [sic] da Península Ibérica. Un estudo do vocabulario da dependencia nos tombos documentais monásticos de Celanova, Samos e Sobrado e no 'Tombo A'da catedral de Santiago, ed. Toxosoutos, Noia, 2010; cuya cronología abarca los siglos IX-XIII), la historiografía castellana dominante en los últimos años se ha fijado para la Plena Edad Media, como mucho, en un fenómeno que le permitía seguir centrando la atención en su tan querido solar castellano-viejo y mantener la fidelidad a viejos fetiches fijados por las interpretaciones de Barbero y Vigil sobre el feudalismo: las behetrías. La obra principal al respecto es Carlos Estepa Díez, Las behetrías castellanas, 2 vols., ed. Junta de Castilla y León, Valladolid, 2003, cuyo autor ofrecería tambien un breve acercamiento al caso leonés en ÍD., "Hombres de benefactoría y behetrías en León (ss. XI-XIV). Aproximación a su estudio", El lugar del campesino. En torno a la obra de Reyna Pastor, Ana Rodríguez (ed.), ed. Universitat de València - C.S.I.C., 2007, València, pp. 113-139. Por el contrario, y más allá de obras clásicas como Eduardo de Hinojosa, El régimen señorial y la cuestión agraria en Cataluña durante la Edad Media, ed. Librería General de Victoriano Suárez, Madrid, 1905 o Jaime Vicens Vives, Historia de los remensas en el siglo XV, ed. Instituto Jerónimo Zurita, Barcelona, 1945, en Cataluña, Aragón y Navarra el tema de la servidumbre plenomedieval sí ha despertado la atención de la investigación reciente en trabajos de primer nivel, aunque está lejos de constituir un polo de interés preferente. Los títulos de referencia son Pierre Bonnassie, La Catalogne du milieu du Xe siècle à la fin du XI siècle. Croissance et mutations d'une société, 2 vols., ed. Université de Toulouse-Le Mirail, Toulouse, 1975-1976; Paul H. Freedman, The Origins of Peasant Servitude in Medieval Catalonia, ed. Cambridge University Press, Cambridge, 1991; Juan José Larrea, La Navarre du IVe au XII siècle. Peuplement et société, ed. De Boeck Université, Bruxelles, 1998; Gaspar Feliu, La llarga nit feudal. Mil anys de pugna entre senyors i pagesos, ed. Universitat de València, València, 2010; y Carlos Laliena Corbera, Siervos medievales de Aragón y Navarra en los siglos XI-XIII, ed. Universidad de Zaragoza, Zaragoza, 2012. A nivel europeo, el balance más actual se ofrece en dos obras colectivas, fruto de coloquios internacionales: el $n^{\circ} 112 / 2$ (2000) de los Mélanges de l'École Française de Rome. Moyen Âge, dedicado monográficamente a "Les formes de la servitude. La servitude dans les pays de la Méditerranée occidentale chrétienne»; y Paul H. Freedman y Monique Bourin (eds.), Forms of Servitude in Northern and Central Europe. Decline, Resistance and Expansion, ed. Brepols, Turnhout, 2005. 
por el habla de la época ${ }^{9}$, es evidente que no toda la documentación altomedieval está redactada en un léxico romance patrimonial. A veces los escribas se lanzan a designar las realidades cotidianas con términos arcaicos y rebuscados, por razones que pueden ir desde la búsqueda de precisión expresiva o la voluntad de conectar con el pasado hasta un exhibicionismo pedante mal disimulado.

Este tipo de cultismos son el peor amigo del historiador, y por desgracia el vocabulario servil altomedieval está lleno de ellos. Empezando por el propio «servus», caso que requeriría un análisis pormenorizado en el que no puedo detenerme aquí. Baste indicar que hay indicios suficientes como para sospechar que, como forma específica de designación de la esclavitud u otras formas estrechas de dependencia, el término parece haber permanecido a lo largo de la Alta Edad Media -al menos dentro del dominio lingüístico asturleonés, que conozco mejor, pero muy probablemente en todo el noroeste hispánico- como un cultismo ajeno al léxico patrimonial, pasando a la lengua romance ya en el nuevo contexto lingüístico y cultural de los siglos XII-XIII, sobre todo a partir de las traducciones del Fuero de León y el Liber Iudicum ${ }^{10}$.

Frente a los cultismos cobran especial valor los neologismos, pues es más probable que se ajusten mucho mejor a las nociones de los contemporáneos (de otro modo no se explicaría su repentina intrusión textual), aunque nos aparezcan bajo un ropaje más o menos dignificado y latinizante. De ahí la primacía que, como veremos, le otorgaré al

\footnotetext{
$9 \quad$ Sobre las relaciones entre escritura y lengua hablada en la Alta Edad Media son especialmente sugerentes las reflexiones de Roger Wright, Latín tardio y romance temprano en España y la Francia carolingia, ed. Gredos, Madrid, 1989.

10 En los textos altomedievales aparece con mucha más frecuencia dentro de fórmulas piadosas o de humildad (servus vester, servus Dei, servus servorum Dei...), cláusulas genéricas (a menudo inspiradas en el Liber) o textos jurídicos (el propio Fuero de León) que como forma de designación concreta de esclavos en la documentación común. De hecho varios autores han resaltado cómo muchas veces parece indicar una mera idea de servitium o de sumisión, como señala Carlos de Ayala Martínez, "Relaciones de propiedad y estructura económica del reino de León: los marcos de producción agraria y el trabajo campesino (850-1230)", El reino de León en la Alta Edad Media, VI, ed. Centro de Estudios e Investigación "San Isidoro", León, 1994, pp. 93-4. Así por ejemplo, como mera argucia legal parece utilizarse la noción de servitium regis en 1078, asimilándola a la idea de servus regis para resolver una problemática donación realizada en el pasado bajo coacción de un conde de Asturias por cierto presbítero Gevuldo: una pesquisa determina que éste es "cum tota generatione sua de pertinentia et servitium regis", lo que permite al monarca aprovechar la vieja norma legal que prohíbe a un servus donar sin consentimiento de su señor para anular la donación sin entrar en el fondo del problema, evitando la amonestación directa a la familia condal $\left(\mathrm{SVO} \mathrm{n}^{\circ} 76\right)$. Por otro lado, los textos relativos a la dependencia personal efectiva y concreta suelen preferir otra terminología distinta a servus (mancipium, criacion... incluso puer). La impresión es que, en un proceso para nada extraño en lexicografía, servus debió de cobrar ya antes de la Alta Edad Media un sentido tan genérico, asociado vagamente a la idea de servitium o como mucho cierta noción de inferioridad (lo que justificaría su uso como fórmula de humildad), que el lenguaje común tuvo que echar mano de otros términos para seguir designando a los esclavos. Y parece evidente que su incorporación tardía a la lengua romance tuvo que venir por otras vías, pues -a diferencia de lo que ocurre por ejemplo en francés, donde sí pasó al léxico patrimonial y es famosa la analogía de Marc Bloch entre la evolución léxica servus > serf y la evolución social homóloga esclavo>siervo-ni en asturleonés ni en castellano el término siervo parece haber tenido en época medieval ninguna connotación relacionada específicamente con la dependencia personal, como sería esperable si fuese la continuación de un término patrimonial para referirse a los esclavos. Véase la contraprueba con el caso mancipium $>$ mançebo.
} 
término criazón. Por tanto, siempre hay que leer los documentos de la época-sobre todo si tratamos de analizar instituciones sociales- teniendo en cuenta la sombra de la lengua romance como subtexto, lo cual nos librará de algunos errores. Por ejemplo, Pierre Bonnassie hizo famosa la asimilación del término «mancipium» con una ideología esclavista más cercana al sistema social antiguo, y varios autores le han seguido a la hora de datar la decadencia del régimen esclavista en función del descenso o desaparición del vocablo en la documentación ${ }^{11}$. Pero ello supone olvidar un hecho fundamental: independientemente de la aparición o no del término latino en los textos escritos, sabemos que nunca dejó de utilizarse en la lengua hablada, pues era una palabra patrimonial que ha dado continuadores tanto en catalán (massip) como en los romances occidentales de la Península (mançebo). Y, lo que es todavía más interesante, por ejemplo en el dominio asturleonés el término aflora ya arromanzado en los siglos XII-XIII para designar a los empleados domésticos y los asalariados rurales ${ }^{12}$. Es decir, precisamente el tipo de mano de obra que sustituye a los viejos esclavos alimentados directamente por el amo: los domésticos, que residían con él, y aquéllos que trabajaban en la reserva señorial. En un análisis lexicográfico retrospectivo, ello parece reforzar notablemente la hipótesis, ya señalada por varios autores, de que cuando en la documentación altomedieval nos topamos con un mancipium es posible que las más de las veces el término aluda específicamente al tipo de esclavos o dependientes personales más vinculados a su amo (domésticos, artesanos y trabajadores rurales vinculados estrechamente a la reserva), no a los instalados en parcelas a cambio de una renta en régimen de pseudo-colonato ${ }^{13}$.

También es la conexión romance la que nos permite detectar la contaminación entre la terminología relativa a la inferioridad social y la juventud (puer, iunior), hasta el punto de que llegó a incorporar también esta segunda acepción a un término como mançebo en principio carente de dicha connotación, pero que al ser una de las formas por antonomasia de designación de los dependientes necesariamente tuvo que acabar por asimilar ese matiz ${ }^{14}$. Conviene recuperar aquí la idea del romance como subtexto: cuando nos encontramos que en determinados contextos los dependientes son designados con términos marcadamente cultos y ajenos al léxico patrimonial como son los de puer y iunior, los cuales originariamente sólo indicaban juventud, cabe preguntarse si no estarán queriendo traducir un término romance considerado quizá como demasiado vulgar.

\footnotetext{
11 Pierre BonNASSIE, "Supervivencia y extinción del régimen esclavista...", pp. 71-3 y p. 75, nota 225; ÍD., "Los campesinos del reino franco en tiempos de Hugo Capeto y de Roberto el Piadoso (987-1031)", Del esclavismo al feudalismo..., pp. 143-4. Le sigue por ejemplo en esa metodología, para el noroeste peninsular, Marcos Fernández Ferreiro, Servos e escravos..., p. 55.

12 Un tipo de "asalariado" (son frecuentes las alusiones a su soldada) que por supuesto está lejos de ser una mera relación contractual de tipo capitalista, y parece guardar todavía ciertos matices de dependencia, como ocurre también con los propios trabajadores domésticos: Carlos de Ayala Martínez, "Relaciones de propiedad...", pp. 342-344; ÍD., "El yuguero castellano-leonés: problemas en torno a sus orígenes (siglos X-XIII)", Historia. Instituciones. Documentos, 20 (1993), p. 46, nota 92.

13 Lo señala por ejemplo para Galicia Marcos FernándeZ FerReIro, Servos e escravos altomedievais..., pp. 55-9.

14 Ya en el año 1098 se utiliza "mancipio" en el sentido de "hombre joven" en Eslonza n 67.
} 
Y lo cierto es que sí existe un vocablo que combina las nociones de dependencia personal y juventud, notablemente vulgar, y que -a diferencia por ejemplo de mancipium- nunca encontramos utilizado junto a puer o iunior: el ya mentado criazón. De hecho, como veremos, parece haber sido la forma genuinamente romance para designar a los esclavos asturleoneses de la Alta Edad Media. Evidentemente no podemos afirmar de manera categórica que tales cultismos estén traduciendo o enmascarando en todos los casos un criazón efectivo (en particular para el caso de iunior parece sugerente también que sea el mero antónimo de senior en sentido social; vid. infra nota 26), pero creo que ha quedado claro que todo análisis del léxico de la esclavitud altomedieval será estéril si no tiene en cuenta que las gentes altomedievales tenían la rara costumbre de hablar, y no precisamente en latín.

\subsection{La tiranía de los modelos}

La tradición historiográfica nos ha legado dos imágenes poderosas que condicionan nuestra visión del problema. De un lado, el esclavo-mercancía de la Antigüedad, más res que persona, que vive en una suerte de establo y trabaja a destajo en batallones disciplinados bajo el implacable poder del látigo. Del otro, el "siervo" de la Edad Media, a quien vemos felizmente establecido en una explotación familiar, provisto de condición humana gracias a la benéfica influencia del Evangelio ${ }^{15} \mathrm{y}$ dotado incluso por la costumbre de ciertos derechos de posesión sobre la tierra que trabaja. El contraste de ambas estampas nos transmite un mensaje reconfortante: existe, en efecto, el Progreso. Con ello se legitima nuestra fe en esa ley arcana según la cual la Humanidad avanza a paso lento pero inexorable «desde las tinieblas primitivas hacia la luz» ${ }^{16} \mathrm{y}$ vemos confirmado que, pese a todo, el cristianismo es la mejor de las religiones posibles.

15 Encontraremos pocos ejemplos más contundentes de esta convicción historiográfica que el que ofrecía el historiador ovetense Ramón Prieto Bances en su clásico estudio sobre el dominio del monasterio de San Vicente, publicado originariamente en los años 1937-1941 como una serie de artículos en el Boletim da Faculdade de Direito da Universidade de Coimbra durante el exilio portugués al que se acogió el antiguo (y breve) ministro de Lerroux, mientras se dirimía su proceso de depuración en la Universidad española, del que acabaría saliendo airoso precisamente gracias en parte a su religiosidad: Ramón PRIETo BANCES, "La explotación rural del dominio de San Vicente de Oviedo en los siglos X al XIII (notas para su estudio)", Obra escrita, ed. Universidad de Oviedo, Oviedo, 1976, vol. I, pp. 162-163: "el panorama de la villa norteña en la época de Augusto no sería muy distinto al que contempló el Cid cuando fue a adorar el arca santa. Y sin embargo la villa del mundo medieval ya no es la misma. Entre los dos mundos hay el Evangelio. No se podrá nunca explicar nuestra historia sin acudir al espíritu cristiano que la anima y menos aún la de aquella patria que nace impregnada toda ella de religiosidad. En la villa asturiana ya no hay rebaños de esclavos, hay masas de hombres. Alfonso II, en el Concilio de Oviedo, restablece las leyes visigodas tanto en la Iglesia como en Palacio y en las leyes visigodas se recogieron los sabios cánones toledanos llenos de amor, de caridad". La reflexión resulta casi enternecedora, hasta que recordamos la extrema dureza de la ideología esclavista recogida en las leyes y concilios visigodos y reconocemos en tanto amor y caridad una fría máscara de cinismo.

16 Elizabeth y Tadeo I. CAmpuzano, "Al lector", nota preliminar a James Frazer, La rama dorada. Magia y religión, ed. Fondo de Cultura Económica, México, $1951^{2}$, p. 9: "donde puede verse el desfile, en exposición del folklore universal, ordenada por la mente genial del autor, de la humanidad caminando tortuosa y dramáticamente a tientas hacia el progreso, desde las tinieblas primitivas hacia la luz" (la nota de los Campuzano, traductores de la obra al castellano, está fechada en 1943). 
No negaré las virtudes balsámicas de esa perspectiva para algunas conciencias, pero, lamentablemente, el recurso a tales modelos no puede ofrecernos mucho más que eso. Si queremos tratar de comprender la naturaleza de estas relaciones sociales de explotación conviene abandonar la visión teleológica de la Historia como una sucesión de dioramas y optar por una perspectiva abierta que huya de toda reificación de las categorías. Es decir, no se trata tanto de responder a preguntas del tipo de si en determinada época todavía eran esclavos o si ya eran siervos como de ensayar un análisis comprensivo en torno a las relaciones de dependencia en una sociedad concreta ${ }^{17}$.

\section{El caso asturleonés}

El panorama que nos muestran las fuentes asturleonesas para los siglos IX al XIII ${ }^{18}$ es más complejo que la convencional dicotomía que acabamos de esbozar, y quizá menos esperanzador. No se ajusta a ninguno de ambos modelos, ni tampoco a una hipotética situación evolutiva intermedia. El gran relato, el feliz gran relato de la evolución de la esclavitud a la servidumbre -entendida ésta como colonato- resulta aquí sencillamente inoperante. A fin de cuentas, a los hombres adquiridos en 1172 por el monasterio asturiano

\footnotetext{
17 Marc Bloch nos muestra el camino con unas reflexiones en las que problematiza la cuestión de la dependencia personal en época carolingia: "Dans cette bigarrure, dans ce flou, résident deux grandes leçons d'histoire sociale. D'abord, qu'un classement juridique n'est pas une réalité en soi, mais une sorte de prise de conscience plus ou moins obscure qu'une société exerce sur elle-même; un homme est, après tout, ce qu'on estime qu'il est. En second lieu, que dans une société à la fois fort ancienne et traversée par des ferments jeunes, nous assistons presque forcément à une sorte de lutte entre les classifications traditionnelles et les rapports nouveaux, introduits par un état social de fait et encore mal reconnus par un droit qui se cherche. Tel était exactement le cas dans la Gaule carolingienne» (Marc BLoch, Seigneurie française et manoir anglais, ed. Librairie Armand Collin, Paris, 1960, p. 43). El tono didáctico se debe a que la obra recoge el texto de lecciones impartidas por el autor en la Sorbona en 1936.

18 A diferencia de lo que se ha postulado para otros territorios, en el noroeste peninsular no se detecta ninguna cesura importante en las formas de dependencia personal en torno al año 1000, sino que éstas parecen tener aún una gran vigencia en los siglos XI-XII y al menos en ciertas zonas perviven hasta la primera mitad del siglo XIII, cuando todavía las encontramos documentadas en algunos tumbos. Por desgracia, el abismo historiográfico que existe por lo general dentro del medievalismo hispano entre las temáticas, referentes y enfoques de los investigadores dedicados a la Alta o Baja Edad Media ha producido la paradoja de que los escasos trabajos que abordan el problema de la esclavitud en la región rara vez superen el límite psicológico del año 1038, dejando por tanto fuera de su análisis buena parte de los ricos testimonios al respecto de los siglos XI-XIII, mientras que los investigadores dedicados a la etapa plenomedieval apenas prestan atención al fenómeno, convencidos sin duda de que es una cuestión que concierne exclusivamente a sus colegas de la Alta Edad Media. Para cubrir una laguna historiográfica tan notable urge romper tales barreras temáticas y cronológicas; por el momento hay que acudir a dos excelentes trabajos que, sin estar dedicados específicamente al tema, abordan la cuestión con gran rigor dentro de un marco diacrónico amplio: Carlos de Ayala Martínez, "Relaciones de propiedad..."; y Miguel Calleja Puerta, El conde Suero Vermúdez, su parentela y su entorno social. La aristocracia asturleonesa en los siglos XI y XII, ed. KRK, Oviedo, 2001, pp. 333-345. Vid. además Gonzalo Martínez Díez, "Servidumbre, ingenuidad y privilegio: notas a la condición jurídica de las personas en el reino de León (910-1157)", Monarquía y sociedad en el reino de León. De Alfonso III a Alfonso VI, ed. Centro de Estudios e Investigación "San Isidoro", León, 2007, vol. I, pp. 573-674, donde se ofrece en pp. 579-599 un repaso más bien descriptivo de las referencias documentales a la dependencia personal en diversas regiones del norte peninsular durante los siglos X-XII.
} 
de Lapedo (Belmonte) a cambio de algunas cabezas de ganado ${ }^{19}$ el progreso conseguido desde que Alfonso II donase varios mancipia a la iglesia de Oviedo 360 años atrás ${ }^{20}$ debía de parecerles cuando menos un tanto discutible. De hecho, el carácter arcaizante de esta forma de dependencia personal tan estrecha queda de manifiesto en que aparece especialmente arraigada en las regiones del solar primitivo del reino asturleonés, donde no se experimentó una ruptura social significativa con motivo de la invasión islámica y la aristocracia pudo mantener por tanto sus bases patrimoniales tradicionales, como en Galicia $^{21}$, el Bierzo ${ }^{22}$ o Asturias ${ }^{23}$.

19 Belmonte n 75: "facimus cartam venditionis de Kabeza de Monte, excepto Pelagio Moruga, Sancia cum filiis suis, Dona cum filiis suis, Gelvira cum filiis suis, Esidorus cum filiis suis et cum fratribus suis Elvira, Marina, Iohannes". La redacción resulta confusa, y Miguel Calleja PuerTa, El conde Suero Vermúdez..., p. 734, nota 83, considera que en realidad lo que se vende es la propiedad de Cabeza de Monte, con excepción de los hombres que la pueblan. Pero el propio documento se refiere más adelante a lo vendido expresa y exclusivamente como "criazón", no como bien inmueble: "Damus vobis supradicta criacione, ut habeatis..." (y todavía más adelante, en la cláusula sancional: "in super pariat vobis ... quingentos morabetinos et duplet ipsa criacione"), por lo que no caben dudas sobre que el objeto de la venta son hombres, no tierras. Probablemente la confusión provenga ya del editor del documento, que aunque entiende también que lo vendido son las criazones, considera a "Cabeza de Monte" como topónimo. Todo encaja mejor si consideramos que "kabeza" alude en realidad no al lugar, sino a los hombres vendidos. Un famoso documento no muy lejano en el tiempo -data de algún momento del reinado de Alfonso IX- se refiere precisamente a la figura del dependiente personal como "iunior de cabeza": Eduardo de Hinojosa, Documentos para la historia de las instituciones de León y Castilla (siglos X-XIII), Madrid, Centro de Estudios Históricos, 1919, doc. $\mathrm{n}^{\circ} 89$. Así pues, el documento de 1172 presentaría la venta de la "kabeza" (es decir, los dependientes personales, las criazones) del lugar de Monte, con excepción de los señalados. $\mathrm{O}$, más aún, dado que es rarísimo que en las enajenaciones de hombres de criazón no se especifiquen sus nombres, cabría pensar incluso que el topónimo es en realidad Monte Excepto, y la nómina de dependientes se refiere a los efectivamente vendidos. No podemos asegurarlo, claro, pero lo cierto es que bastaría optar por una tipografía diferente en la edición del texto para que esta alternativa resultase menos extraña: "facimus cartam venditionis de kabeza de Monte Excepto: Pelagio Moruga, Sancia cum filiis suis... (etc.)". De lo que no parece caber duda es de que, sea el topónimo Monte y la nómina personal aluda a los exceptuados de la venta, o sea Monte Excepto y se nombre a los efectivamente vendidos, el objeto del negocio son hombres de criazón, no tierras.

$20 \mathrm{CCO} \mathrm{n}^{\circ} 2$ (812).

21 Un análisis de los tipos de dependencia campesina, desde presupuestos clásicos muy reacios a la admisión de formas esclavistas, en Amancio Ista Frez, La sociedad gallega en la Alta Edad Media, ed. C.S.I.C., Madrid, 1992, pp. 203-214. Además, sobre la terminología de la dependencia personal en Galicia es de consulta obligada Marcos Fernández Ferreiro, Servos e escravos altomedievais..., aunque el uso exclusivo de documentación recogida en tumbos de los siglos XII-XIII obliga a tomar los resultados lexicográficos con cierta cautela.

22 Con documentos tan significativos como CCA n 20 (970?), en el que un abad menciona cómo había comprado algunos esclavos sarracenos, o CCA n ${ }^{\circ} 171$ (992), donde el rey Vermudo II dona al monasterio de Santa Leocadia de Castañeda nada menos que 91 hombres de criazón en El Bierzo. M ${ }^{a}$ del Carmen Rodríguez GonzÁlez y Mercedes Durany Castrillo, "Ocupación y organización del espacio en el Bierzo Bajo entre los siglos V al X”, Studia Historica. Historia Medieval, 16 (1998), pp. 82-4, califican rotundamente de esclavos a estos dependientes personales y señala su importancia en la explotación de los dominios aristocráticos altomedievales. Además, Mercedes Durany Castrillo, La región del Bierzo en los siglos centrales de la Edad Media (1070-1250), ed. Universidad de León - Universidade de Santiago de Compostela, León Santiago de Compostela, 1989, p. 239, nota 835, postula que pese a la escasez de menciones documentales, en la Plena Edad Media la servidumbre seguía siendo importante en el medio rural.

23 Miguel Calleja Puerta, El conde Suero Vermúdez..., pp. 333-345. 
La triste realidad que nos encontramos a lo largo de todo el periodo es por tanto la persistencia -recalquémoslo: persistencia, no aparición- de formas muy duras de dependencia personal que juegan un papel capital en la explotación de los dominios aristocráticos, especialmente al norte de la Cordillera Cantábrica ${ }^{24}$. Así, junto a las relaciones de dependencia basadas en la explotación de la tierra, en las que bajo diversas fórmulas el cultivador de un solar ajeno queda sujeto al dominio del propietario del suelo (conservando la libertad de abandonarlo a voluntad, generalmente previo pago de una compensación), existen individuos sujetos a su dominus por un vínculo personal de carácter absoluto, imborrable y hereditario, con independencia de que trabajen o no las tierras de éste.

En Asturias y León las fuentes les dan diversos nombres: a menudo los encontramos mencionados a través de términos imprecisos que aluden de modo genérico a la dependencia o la inferioridad social (homines ${ }^{25}$, iuniores $^{26}$ ), o enmascarados bajo un abanico

24 Incluso Reyna PAStor DE Togneri, "Formación y consolidación del feudalismo castellano-leonés. Siglos X-XIII", La génesis del feudalismo en el mundo mediterráneo, Antonio Malpica y Tomás Quesada (eds.), ed. Universidad de Granada, Granada, 1994, p. 125, considera que el esclavismo constituyó, al menos, un "modo de producción secundario" en Asturias y Galicia.

25 Claudio SÁnchez-Albornoz, "Homines mandationis y iuniores", Viejos y nuevos estudios sobre las instituciones medievales españolas, tomo I: Instituciones sociales, ed. Espasa-Calpe, Madrid, 1976 ( $2^{\mathrm{a}}$ ed. ampliada), p. 548: "Se venía usando y aun abusando de la palabra homines para designar a los miembros de los más variados grupos sociales en alguna manera en dependencia".

26 La historiografía institucionalista ya se enfrentó en su momento a las características aparentemente contradictorias de las que aparecían revestidos los iuniores en las fuentes, singularmente en el Fuero de León, donde algunas cláusulas los presentan dotados de libertad de movimientos, mientras que en otras aparecen sujetos por un vínculo personal a su señor. El problema fue resuelto al aplicar a la época altomedieval la división entre iunior de cabeza y iunior per hereditatem que establecía un decreto de Alfonso IX, entendiendo a los primeros como dependientes personales y a los segundos como hombres libres sujetos a dependencia por cultivar un predio ajeno que podían abandonar a voluntad: vid. el texto en Eduardo de Hinojosa, Documentos para la historia de las instituciones de León y Castilla (siglos X-XIII), ed. Centro de Estudios Históricos, Madrid, 1919, doc. n 89, así como las páginas dedicadas a la cuestión en el elegante y didáctico artículo de Alfonso García-Gallo, "El hombre y la tierra en la Edad Media leonesa (El prestimonio agrario)", Revista de la Facultad de Derecho de la Universidad de Madrid, 2 (1957), pp. 334-342. Lo más probable no obstante es que la de iunior no fuese en la Alta Edad Media una categoría jurídica precisa, sino una mera etiqueta de inferioridad social, reverso exacto de senior. Como dice Alfonso GARCíA-GALlO, "El hombre y la tierra...", p. 340: "la palabra iunior designa, en general, a todo sometido a un senior o dominus, sin especificar una clase determinada de sujeción"; si bien es cierto que al menos un pleito del año 1050 sobre los hombres dependientes de los monasterios de Prendonés y Cartavio, en el occidente asturiano, opone con toda nitidez los geniores et ingenuii a los servi vel mancipia (LTO $\mathrm{n}^{\circ} 43$ ). Aunque el término iunior tiene todo el aspecto de un cultismo y aparece muy raramente mencionado en las fuentes de archivo como categoría social (CCL n ${ }^{\circ}$ 1026, año 1045; Eslonza n 42, año 1071; Gradefes $n^{\circ}$ 9, año 1088; CCL no 1295, año 1098), en algunos casos se documenta la forma geniores - LTO $n^{\circ} 43$ (1050); LTO no 46 (c. 1090); RC, p. 188 (1144) - que sí parece atestiguar una cierta evolución romance, la cual pese a todo no parece haber arraigado lo suficiente en la lengua asturleonesa como para haber dejado un heredero moderno. La mención más tardía que he encontrado de una forma romance de iunior data de una copia en gallego (siglo XIII?) del fuero de Villafranca del Bierzo, perteneciente a la familia del fuero de León y otorgado en 1192 (sin duda originalmente en latín), que traduce el iunior latino mediante el término geor: Justiniano Rodríguez Fernández, Los fueros del reino de León, vol. II: Documentos, ed. Ediciones Leonesas, León, 1981, doc. $\mathrm{n}^{\circ}$ 50, p. 151. En cambio, las diversas versiones romanceadas del 
de cultismos (pueri, puellae, ancillae, servi...). Pero la denominación genuina, por su sabor netamente romance, parece haber sido la de «criazones» u «omnes de criazón», que ya desde el siglo $\mathrm{X}$ es recogida en los documentos bajo diversas formas más o menos latinizantes: criazon, creationem, criacione, homines de nostra criazon, homines de creatione... El término apela a su condición de dependientes por nacimiento y además los emparenta sin escrúpulos con el ganado (también las crías de animal son denominadas criazones $^{27}$ ), dentro del cual la tradición antigua situaba formalmente a los esclavos ${ }^{28}$. También, en un sentido más restringido, parece haber sido patrimonial el término «mançebo» (mancipium, $-o,-a$; incluso mancipella), que como hemos visto se reservaba posiblemente para designar a esclavos que, como los domésticos, eran alimentados directamente por el amo y no vivían instalados en parcelas ${ }^{29}$.

Claro que estamos muy lejos de aquel medio social poblado de esclavos que caracterizó a las economías de plantación del Mediterráneo clásico, con un comercio esclavista tan extendido que incluso en las zonas menos opulentas del Imperio Romano la posesión de uno o dos de estos dependientes personales podía estar al alcance de familias no demasiado acomodadas. En el reino asturleonés los esclavos aparecen como patrimonio prácticamente exclusivo de la gran aristocracia, empezando por los reyes y las principales instituciones eclesiásticas ${ }^{30}$. Pero eso tampoco significa que se trate de un fenómeno esporádico o residual: no estamos hablando meramente de la esclavitud doméstica, que

fuero de León, que datan del siglo XIII o comienzos del XIV, ya traducen iunior por mancebo forero u ome forero: Tomás MuÑoz y Romero, Colección de fueros municipales y cartas pueblas de los reinos de Castilla, León, Corona de Aragón y Navarra, ed. Imprenta de Don José María Alonso, Madrid, 1847, tomo I, pp. 77 y 80; Francisco Javier Fernández Conde y Xosé Lluis García Arias (eds.), Fueru de Lleón y Conceyu de Coyanza. Edición facsimilar de dos testos del sieglu XIII na nuesa llingua, ed. Academia de la Llingua Asturiana, Uviéu, 2009, pp. 25, 27 y 31. Por su parte, la versión romance otorgada por Alfonso X en 1263 del fuero latino de Sanabria de 1220 mantiene el vocablo en su forma latina, como un arcaísmo o término técnico de imposible traducción: "Si algún junior de cabeza o siervo que non sea conocido..." (Alfonso Garcia-Gallo de Diego, "El fuero de León. Su historia, textos y redacciones", Anuario de Historia del Derecho Español, 39 (1969), Apéndice III, p. 163).

27 CCL no 703 (1011): "oues LXXX $X^{a}$ cum sua criacione"; SV1 no 52 (1055): "damus tibi in prestamo equa colore morcella, medietate in ea (...) et criatione quem fecerit similiter per mediam aueas ab omni integri-

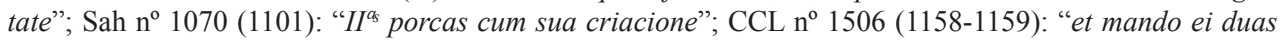
uaccas integras in Torneros, et medietatem aliarum duarum, cum creatione sua".

28 Pierre BonNASSIE, "Supervivencia y extinción...", pp. 30-2. Conviene no obstante tener en cuenta que en la Baja Edad Media el término "criazón" también designaba a la prole humana, sin connotación de inferioridad social, aunque no parece haber ejemplos altomedievales de dicha acepción. Recoge algunos testimonios literarios de los siglos XIII-XIV en este sentido Ramón Prieto Bances, "Los «amigos» en el Fuero de Oviedo", Anuario de Historia del Derecho Español, 23 (1953), pp. 216-217.

29 Cuestión aparte son esas figuras mal conocidas de trabajadores sin tierras que Carlos de Ayala MarTínez, "Relaciones de propiedad...", pp. 198-9, considera muy cercanos a la dependencia personal. Un ejemplo clásico por su pervivencia bajomedieval es el yuguero, a cuyos orígenes altomedievales el mismo autor dedicó un estudio específico: Í̀., "El yuguero castellano-leonés...".

30 Lo señalan para el caso cántabro José Ángel García de Cortázar y Ruiz de Aguirre y Carmen Díez Herrera, La formación de la sociedad hispano-cristiana del Cantábrico al Ebro en los siglos VIII a XI. Planteamiento de una hipótesis y análisis del caso de Liébana, Asturias de Santillana y Trasmiera, ed. Librería Estudio, Santander, 1982, p. 188; y para Asturias Miguel Calleja Puerta, El conde Suero Vermúdez..., p. 345 , quien documenta también un ejemplo referido a la pequeña nobleza local. 
perdurará a lo largo de toda la Edad Media, sino de una esclavitud productiva en la que estos dependientes personales aparecen dedicados a actividades económicas relacionadas con la agricultura o la artesanía. Lejos de constituir un mero atributo lujoso de distinción social, los esclavos altomedievales jugaban un papel de primer orden en la vida económica, y es precisamente la evolución de esta esclavitud productiva la que resulta históricamente relevante, como puso de relieve Pierre Bonnassie ${ }^{31}$.

\section{Mejor que definir, comprender}

Aunque la enajenación de seres humanos en el reino asturleonés no deja lugar a dudas acerca de su consideración por parte de sus amos como una propiedad más ${ }^{32}$, para abordar el análisis de esta forma de esclavitud - de cualquiera, en realidad - conviene ir más allá del enfoque puramente jurídico, con su rígido paradigma del esclavo-mercancía o esclavo-cosa que es un puro constructo ideológico ${ }^{33}$. Éste jugaba su papel como discurso legitimador del orden social, por supuesto, pero los historiadores deberían ser los últimos en dejarse llevar por tales abstracciones. ¿Acaso alguien puede creer que siquiera los antiguos se tomasen realmente en serio la idea de que los esclavos eran animales o herramientas, cuando tenían ante sus ojos la experiencia cotidiana de cómo hombres libres caían en esclavitud por guerra, rapto o deudas? $?^{34}$

Se ha hecho un uso académico hasta la náusea de la definición del esclavo en la Antigüedad como «instrumentum vocale» ("herramienta dotada de voz"). Casi invariablemente los medievalistas la sacan a colación para contraponerla a la visión pretendidamente más humanitaria del cristianismo, como si la fórmula implicase la negación de la naturaleza humana de los esclavos en el mundo clásico ${ }^{35}$. Incluso es frecuente atribuirla erróneamente nada menos que a Aristóteles ${ }^{36}$, lo cual no deja de resultar irónico, porque

\footnotetext{
31 Pierre Bonnassie, "Supervivencia y extinción del régimen esclavista...”, p. 17.

32 Tenemos un buen ejemplo lebaniego en la carta de donación entre particulares de una mancipella llamada Faquina, donde se recoge una fórmula característica de las transmisiones de bienes: "ita ut ab odierno die post parte vestra iuri quieto posideatis": Luis SÁnchez Belda, Cartulario de Santo Toribio de Liébana, ed. Patronato Nacional de Archivos Históricos, Madrid, 1948, doc. nº 19, año 914.

33 Pierre BonNASSIE, "Supervivencia y extinción del régimen esclavista...", pp. 37-8, señala que todas las sociedades esclavistas - no sería, por tanto, un rasgo original de la época medieval- han sufrido la contradicción entre la voluntad ideológica de convertir al esclavo en un ser infrahumano y el hecho biológicamente evidente de que no lo es.

34 Baste recordar el famoso fragmento 24 de Solón: "A Atenas, nuestra patria fundada por los dioses, devolví muchos hombres que habían sido vendidos, ya justa, ya injustamente (...) A otros, que aquí mismo sufrían humillante esclavitud, temblando ante el semblante de sus amos, les hice libres" (Francisco RodRíguez Adrados, Líricos griegos. Elegíacos y yambógrafos (siglos VII-V a.C.), ed. C.S.I.C., Madrid, 1990², vol. I, pp. 201-2). Según la tradición, el propio Platón habría sido vendido como esclavo, teniendo que ser rescatado por un amigo.

35 Así en Max Weber, "La decadencia de la cultura antigua. Sus causas sociales", La transición del esclavismo al feudalismo, ed. Akal, Madrid, 1989, p. 57; o Marc BLoch, "Cómo y por qué terminó la esclavitud antigua", La transición del esclavismo al feudalismo, ed. Akal, Madrid, 1989, p. 174.

36 Por ejemplo el propio Pierre BonNassie, "Supervivencia y extinción del régimen esclavista...”, p. 30.
} 
aun cuando la expresión hubiera sido suya, habría quedado invalidada por sus actos: sabemos que al quedar viudo se unió a la esclava Herpyllis y tuvo con ella a su hijo Nicómaco. Evidentemente, debemos suponer que no pretendía con ello engendrar un retoño en una herramienta, y hasta donde yo sé no hay motivos para suponer una particular inclinación de Aristóteles hacia el bestialismo. Pero ocurre que no sólo la máxima no es suya, sino que de hecho el filósofo se refirió al esclavo con una expresión que goza de mucho menos predicamento entre los medievalistas: «empsychon organon» (Ética nicomáquea, VIII, 1161b4), es decir, "herramienta dotada de alma" (psyché) ${ }^{37}$. La autoría del instrumentum vocale corresponde en realidad -parece que el idioma era una pista- a un autor latino: el polígrafo Varrón (siglo I d.C.), quien en su De re rustica (I, 17, I) señala que algunos agrupan los medios necesarios para el cultivo de los campos en dos clases: hombres y todo aquello que éstos necesitan para trabajar; mientras que otros hacen la división entre instrumental parlante, semiparlante y mudo. Recientemente, Juan P. Lewis ha propuesto que el pasaje sería un mero artefacto retórico para referirse en tono pretendidamente erudito a la obvia necesidad de mano de obra en la agricultura, por lo que no debería interpretarse en sentido literal como si Varrón viese en los esclavos a meras herramientas privadas de humanidad, aunque sólo sea porque en el instrumentum vocale estarían incluidos también los trabajadores libres ${ }^{38}$. De hecho, una mera lectura atenta del texto muestra que se limita a ofrecer un ejemplo de cada clase de equipamiento, no una equivalencia completa: «иocale, in quo sunt serui; seminocale, in quo sunt bones; mutum, in quo sunt plaustra ${ }^{39}$. Y, por si quedase alguna duda, inmediatamente a continuación Varrón incluye a los esclavos entre los seres humanos: «Omnes agri coluntur hominibus, seruis aut liberis aut utriusque» $(\mathrm{I}, 17,2)$. Pero, al igual que ocurre con la definición aristotélica del esclavo como "herramienta dotada de alma”, será mucho más difícil encontrar mencionada esta otra máxima varroniana en un trabajo de temática medieval que la tópica referencia al instrumentum vocale.

Claro que citar supone ante todo tomar partido, seleccionar, definir, así que la pregunta resulta obligada: ¿por qué tantos medievalistas han optado por elevar a arquetipo del pensamiento social antiguo una clasificación banal tomada de un tratado de agronomía, sacándola además de contexto para que parezca insinuar una idea -la no-humanidad de los esclavos- sin duda ajena a su autor, mientras al mismo tiempo silenciaban la definición del mayor filósofo de la Antigüedad? La respuesta no parece difícil: cuando se conoce la opinión de Aristóteles, la teoría de la originalidad del pensamiento cristiano sobre los esclavos - uno de los fundamentos historiográficos de la visión clásica sobre el "paso de la esclavitud a la servidumbre", como mínimo desde los autores decimonónicos- recibe un duro golpe.

\footnotetext{
37 Además, en Política, I, 1253b, lo califica de "ktema ti empsychon", es decir, "posesión dotada de alma". 38 Juan P. LewIs, "Did Varro Think that Slaves Were Talking Tools?", Mnemosyne. A Journal of Classical Studies, 66 (2013), pp. 643-8.

39 La interpretación alternativa del pasaje como una lista de equivalencias completas (del tipo instrumentum uocale $=$ serui $)$ obligaría a incurrir en el absurdo de suponer que Varrón no concebía ningún equipamiento agrícola fuera de esclavos, bueyes y carros.
} 
Así pues, una vez liberados de la contra-imagen tópica del instrumentum vocale, que ha servido sobre todo para diferenciar inútilmente a los servi de la Edad Media de unos fantasmales esclavos-cosa que probablemente nunca existieron fuera de los códigos legales, podemos abordar la esclavitud como lo que es en realidad, en la Europa medieval, en el Imperio Romano o en cualquier otra época: una relación social de explotación. Desde este punto de vista, resulta más esclarecedor interpretar el fenómeno de los esclavos altomedievales como una forma de dependencia personal especialmente dura en el marco de la economía señorial. La clave no está en lo que los juristas eruditos pudieran opinar sobre la condición de estos hombres, ni en las palabras más o menos pedantes que pudieran utilizar los escribas para designarlos (servi, mancipia, pueri...), sino en las formas concretas de dominación ejercidas sobre ellos por sus señores y que los diferenciaban del grupo de los "libres", incluso de aquéllos sujetos a otras formas de dependencia, como la encomendación, el colonato o la "mera" jurisdicción señorial. La perspectiva antropológica puede ser especialmente interesante para comprender la situación de este grupo social. La noción clave sería entonces la de exclusión ${ }^{40}$, que de acuerdo con Pastor Díaz de Garayo podríamos ordenar en tres niveles: incapacidad para acceder a la propiedad (no sería dueño siquiera de su propia fuerza de trabajo) ${ }^{41}$; privación de derechos sobre su descendencia, que estaba a merced del amo; carencia de naturaleza política, lo que le inhabilitaba para actuar por cuenta propia por ejemplo en el campo de la justicia ${ }^{42}$. Bonnassie lo resume con una definición formulada en términos socioeconómicos: «el esclavo aparece como un ser desocializado cuya producción y reproducción están completamente controladas por otros ${ }^{43}$. Pero quizás convenga huir de definiciones demasiado rígidas. Recogiendo las propuestas de ambos autores, y retomando un acercamiento antropológico a la noción de exclusión, yo pondría el énfasis en dos tipos de carencia: esclavo sería aquél que tiende a verse privado, en un grado máximo, de autonomía (sobre su trabajo, sobre la gestión de su economía familiar o sobre sus relaciones personales) y de capacidad de participación: en las asambleas judiciales, en las redes de solidaridad aldeana, en los espacios y rituales de enterramiento comunitarios o en las estructuras familiares consideradas legítimas. El esclavo sufre pues una doble alienación: es al mismo tiempo un hombre de otro y un extraño a la comunidad local.

40 Guy Bors, La revolución del año mil. Lournand, aldea del Mâconnais, de la Antigüedad al feudalismo, ed. Crítica, Barcelona, 1991, pp. 28-30.

${ }^{41}$ Conviene recordar que esta incapacidad privaría no sólo del acceso a la propiedad privada, sino también a la comunal, la cual constituye un elemento fundamental en la lógica económica de las comunidades aldeanas.

42 Ernesto Pastor Díaz de Garayo, Castilla en el tránsito de la Antigüedad al feudalismo. Poblamiento, poder político y estructura social del Arlanza al Duero (siglos VII-XI), ed. Junta de Castilla y León, Valladolid, 1996, p. 281, quien se inspira por supuesto en las propuestas de Guy Bois y Pierre Bonnassie. Pero además, en esa misma página, indica en la nota 180 cómo esas características eran ya las que utilizaba Claudio SÁnchez-Albornoz, "Los siervos en el noroeste hispano...", para definir el estatus de este grupo social, al que él denominaba siervos.

43 Pierre Bonnassie, "Supervivencia y extinción del régimen esclavista...", p. 37. 
De este modo, es el contexto el que determina las modalidades y límites dentro de los cuales se manifiesta esa carencia máxima -en sentido siempre relativo, claro- de autonomía y participación. En un medio social como puede haber sido el tardoantiguo, con estructuras estatales (justicia, fisco, ejército) aún relativamente fuertes, grupos de propietarios libres organizados formalmente en asambleas y formas de identidad local basadas en la exhibición de riqueza en las inhumaciones, la diferencia libertad-esclavitud estaría claramente marcada por barreras como el acceso a la propiedad o la participación en los concilia judiciales. Recientemente parece haberse hallado una constatación arqueológica muy clara de esta exclusión de la población esclava en los restos humanos de época tardoantigua cuyos cadáveres -con signos de sobreesfuerzo y malnutrición- aparecen arrojados en fosas (como silos o pozos amortizados), sin indicios de ritual funerario alguno y asociados en ocasiones a restos de animales domésticos, como perros, gatos u ovejas ${ }^{44}$. La imagen de unos hombres y mujeres que se veían privados del acceso al cementerio comunitario y a su muerte eran meramente arrojados a un vertedero, literalmente como animales, explica mejor que cualquier tratado jurídico las condiciones cotidanas de explotación y exclusión en las que vivían. Dentro de nuestra área de estudio contamos al menos con un ejemplo que quizás podría atribuirse a este fenómeno: en el yacimiento de El Pelambre (Villaornate), un pequeño asentamiento del siglo VI situado unos $50 \mathrm{~km}$ al sur de la ciudad de León, en la vega del Esla, se han hallado restos óseos humanos en el relleno de un fondo de cabaña ${ }^{45}$.

Pero en la Alta Edad Media asturleonesa las condiciones de esa doble alienación que hemos señalado estaban empezando a modificarse. Aunque seguía existiendo el comercio de esclavos ${ }^{46}$, la situación había cambiado mucho desde la época clásica y ahora era una forma de abastecimiento mucho menos importante que la propia reproducción natural de los mismos, si bien también seguía jugando su papel la esclavización de cautivos de

\footnotetext{
${ }^{44}$ Alfonso Vigil-Escalera Guirado, "Comunidad política aldeana y exclusión. Una revisión de las formas de inhumación altomedievales (ss. V-VIII d.C.)”, Reti Medievali Rivista, 14/1 (2013), pp. 3-42. El trabajo pionero en ofrecer este tipo de interpretación, al menos a nivel peninsular, parece haber sido Jordi RoIG I Buxó y Joan Manuel Coll RIERA: "Esquelets humans en sitges, pous i abocadors als assentaments rurals i vilatges de l'antiguitat tardana de Catalunya (segles V-VIII): evidències arqueològiques de la presencia d'esclaus i serfs", Actes del IV Congrés d'Arqueologia Medieval i Moderna a Catalunya (Tarragona, del 10 al 13 de juny de 2010), ed. Ajuntament de Tarragona - Associació Catalana per a la Recerca en Arqueologia Medieval, Tarragona, 2011, vol. I, pp. 75-82.

45 Fernando Pérez Rodríguez-Aragón y Ma Luz González Fernández, "El asentamiento de época visigoda de «El Pelambre» (Villaornate, León)", The archaeology of early medieval villages in Europe, Juan Antonio Quirós Castillo (dir.), ed. Universidad del País Vasco, Bilbao, 2009, pp. 366-7.

46 Por ejemplo, documentos como el Testamentum regis Adefonsi del año $812\left(\mathrm{CCO}^{\circ} 2\right)$ o CCA n 20 (970?) aluden con naturalidad a la compra de esclavos. El propio Vermudo III, al condenar en TA $n^{\circ} 67$ (1032) las fechorías de cierto Sisnando Galiáriz - rebelde caracterizado como un verdadero malfechor feudal - en la diócesis compostelana, habla incluso de hombres raptados y puestos en venta como si se tratase de cautivos de guerra: "Iterum venit ad casam de Vimara Vistaraci et rapinavit inde kavallum unum de solidos CC et duxit inde secum sex homines et vendidit illos sicut captivos".
} 
guerra (los mauri de nuestras fuentes ${ }^{47}$, a menudo diferenciados expresamente de los servi o criazones $^{48}$ ) o incluso de hombres libres o dependientes ajenos que, si se daba la ocasión, pudieran ser secuestrados en beneficio propio ${ }^{49}$. Pero lo habitual era ya, sin duda, que los esclavos fuesen trabajadores nativos, lo que contribuía a relativizar su condición de extraños a la comunidad local.

Además, es bien sabido que desde la Tardoantigüedad se venía desarrollando el progresivo abandono del modelo de los "rebaños de esclavos" controlados directamente por la administración dominical en favor de su instalación en tenencias. Aunque, como veremos, los indicios para Asturias apuntan a la vigencia todavía en la Alta Edad Media del trabajo servil en la reserva señorial, por lo que haríamos mal en ver en estos dependientes algo así como unos colonos atados a la tierra y sujetos al mero pago de rentas, como querría el tópico. Lo importante es que el fenómeno de los esclavos $c a-$ sati permite a éstos desarrollar una vida familiar en el marco de unidades domésticas y actuar en la práctica como posesores de parcelas. Esto les acercaba a la situación de otros grupos sociales y permitía que los servi empezasen a ser unas gentes mucho más arraigadas en la comunidad local, con una forma de vida fácilmente reconocible como humana en la que cada vez tenía menos sentido su vieja caracterización como ganado: venían a constituir una especie de campesinos dependientes de segundo orden, sujetos a una infamante mácula servil que los ligaba al señor de manera especialmente estrecha.

Porque aunque el segundo término de su doble alienación (la condicion de extraños a la comunidad local) se estuviese modificando, el primero permanecía plenamente vigente: el esclavo seguían siendo, ante todo, el hombre de otro, en un grado que no conocía ningún otro tipo de dependiente. A diferencia de éstos, el esclavo no sólo no podía escapar a esa sujeción que llevaba «pegada a los huesos» $\rangle^{50}$, por ejemplo entregándose a otro amo, renunciando a su tenencia o abandonando el señorío; sino que además su condición se transmitía de padres a hijos como una mácula imborrable que perduraba durante generaciones: los inventarios señoriales anotan con todo cuidado la sucesión genealógica de estos dependientes personales.

\footnotetext{
47 El mejor estudio de este grupo social para una región del norte peninsular sigue siendo el artículo clásico de Juan Ignacio Ruiz de la PeÑa Solar, "Siervos moros en la Asturias medieval", Asturiensia Medievalia, 3 (1979), pp. 139-161.

48 Otero $^{\circ} 237$ (1045), Otero $n^{\circ} 278$ (1076), Otero no 304 (ppios. del siglo XII?), SMV no 4 (1153).

49 Así, el conde Diego Fernández de Saldaña aprovechó alguno de los desórdenes civiles que sacudieron el reino de León durante el reinado de Vermudo II y la minoría de Alfonso V para despoblar la villa episcopal de Villa Revelle (en la zona del Valle de Ratario, cerca de Sahagún) y llevarse a sus habitantes, instalándolos en una populatione de su propiedad, según narra un documento de 1026 (CCL n 829). También vid. supra nota 46 para el rapto de hombres vendidos a continuación como esclavos.

50 Marc Bloch, Reyes y siervos..., p. 361. La expresión, tomada de un jurista tardío, se refiere a los siervos personales de época posterior, pero puede aplicarse perfectamente a los esclavos altomedievales.
} 


\section{FiguRA 1}

Un ejemplo de genealogía servil: Los ascendientes de María Iustiz y Pelayo Vigo, hombres de criazón del monasterio asturiano de Corias (mediados siglo XI - mediados siglo XII) ${ }^{51}$

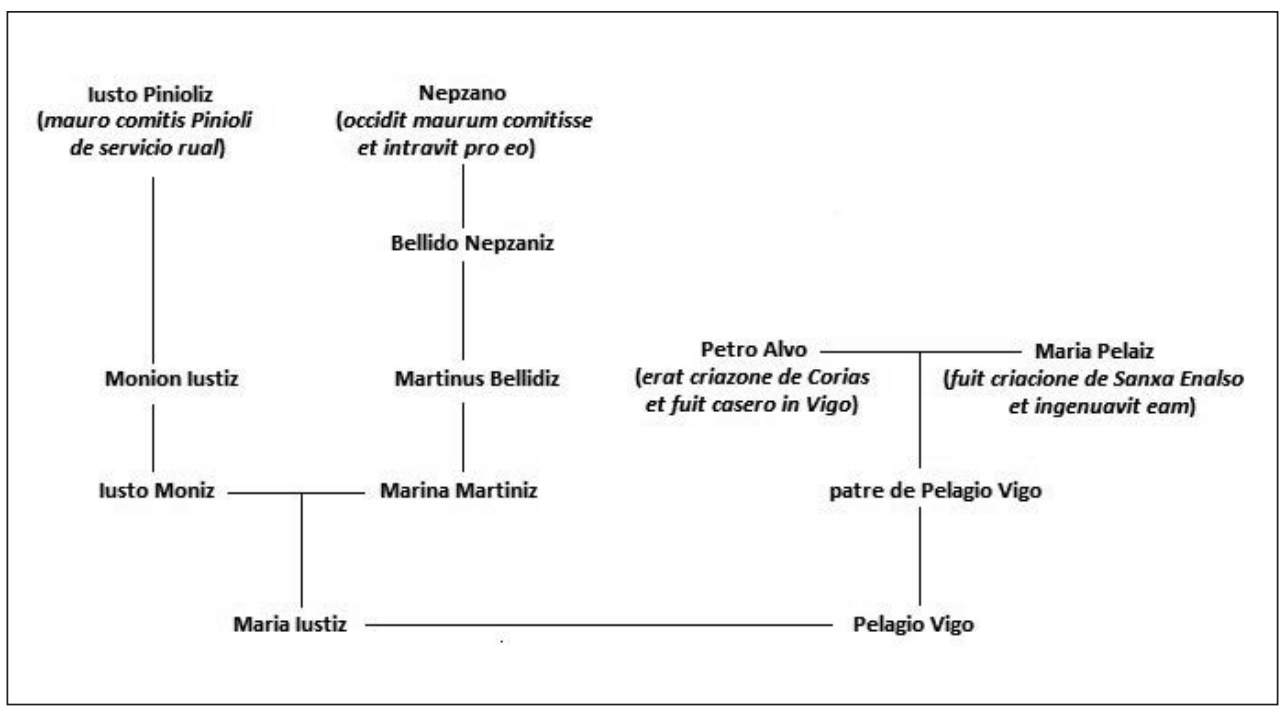

Aunque en la práctica las circunstancias concretas de su existencia pudiesen ser más o menos acomodadas (cultivo de un predio en tenencia o ejercicio de un oficio, estabilidad familiar, arraigo local, incluso reunión de un peculio o ejecución de tareas de responsabilidad por cuenta del señor...), éstas dependían completamente de la voluntad de su dueño, que podía privarles de tales comodidades en cualquier momento. Por eso sería un error verlos ya convertidos en tenentes de pleno derecho (en "siervos" según la imagen tópica): a diferencia de lo que ocurre con los encomendados, los libertos o los meros cultivadores libres de solares ajenos, el amo conserva sobre sus esclavos -instalados o no en parcelas, eso es indiferente- la facultad de ejercer un poder absoluto y arbitrario, no sujeto a límites consuetudinarios.

En particular, sobre los esclavos ya casati pesa una amenaza que no por improbable resulta menos aterradora: la capacidad que tiene su dueño de desarraigarlos completamente, privándolos a voluntad de su identidad local y sus lazos comunitarios. Puede

51 RC, pp. 125-6 (f. 54r). Estos hombres de criazón están vinculados al monasterio de San Martín de Mántaras (Tapia), subordinado al de San Juan de Corias desde el año 1054, cuando le fue donado por la condesa Aldonza. Concretamente el marido de la última descendiente de Nepociano parece pertenecer a una familia servil arraigada en Vigo (Navia). La genealogía arranca en tiempos de los condes fundadores, Aldonza y Piniolo, y se extiende un par de generaciones más allá de la época de Sancha Enalso, a quien encontramos documentada en el último cuarto del s. XI (RC, p. 53, f. 6vA, año 1078; y p. 106, f. 41rA, año 1097). Así pues, su cronología abarca desde la primera mitad del s. XI hasta aproximadamente mediados del XII. 
dividir a las familias de esclavos, despojarlos de las tierras que ocupan, encargarles un nuevo oficio o llevárselos a trabajar en otro de sus dominios. Por motivos evidentes no es de esperar que tales situaciones se produjesen con mucha frecuencia, pero el mero hecho de contar con dicha posibilidad debía de funcionar como un mecanismo de coacción especialmente efectivo ${ }^{52}$. Y aunque en las enajenaciones de esclavos es por lo general imposible determinar cuándo ha habido separación de familiares, sí que contamos con algunos ejemplos documentados de traslados de dependientes personales de una propiedad a otra de sus amos, como veremos en el próximo apartado.

\section{El papel del esclavismo dentro de la economía señorial en Asturias y León}

Aunque quizá los tiempos ya no sean propicios para hacer ejercicios de escolástica marxista, puestos a hablar de esclavismo recordemos que el núcleo del problema sobre la caracterización de una sociedad como esclavista no reside en determinar el número o la proporción de los esclavos con respecto a los trabajadores libres, sino en la importancia que la explotación del trabajo no-libre juega dentro de los mecanismos de apropiación del excedente por parte de la clase dominante ${ }^{53}$. Cuando tantos medievalistas -incluso pretendidamente marxistas, lo cual produciría cierto sonrojo de no ser porque todos sabemos que el "marxismo" nativo fue en la mayoría de los casos poco más que un mecanismo de legitimación simbólica o adscripción grupal- recurren al expediente simplista de negar la idea de un esclavismo en la Alta Edad Media aduciendo que ni los esclavos constituían una mayoría social ni recaía en sus manos la mayor parte de la producción, olvidan que -quizá con algunas excepciones muy acotadas en el espacio y en el tiempo, como la Sicilia tardorrepublicana- ello tampoco ocurría en la Antigüedad ${ }^{54}$. Así que de seguir coherentemente su propia línea argumental (inexistencia de una mayoría de es-

52 En particular, la importancia coactiva que tiene la amenaza de ruptura de la familia esclava por parte de sus dueños es puesta de relieve en G. E. M. de Ste. Croix, La lucha de clases en el mundo griego antiguo, ed. Crítica, Barcelona, 1988, pp. 178-9 y 479.

53 Vale la pena recordar que ése es precisamente el planteamiento mantenido en la que debería ser la obra de referencia sobre la sociedad antigua desde un análisis marxista, un trabajo por otra parte delicioso y fecundo como es G. E. M. de Ste. Croix, La lucha de clases..., pp. 70-1: "el rasgo distintivo más significativo de toda formación social, de cada «modo de producción» no estriba tanto en cómo se realiza el grueso del trabajo de producción, cuanto en cómo las clases propietarias dominantes, que controlan las condiciones de producción, se aseguran la extracción del excedente que hace posible su propia existencia sin necesidad de trabajar. Este es el punto de vista de Marx, y yo lo sigo (...) Podemos, pues, hablar del mundo griego antiguo como de una «economía esclavista» (en el sentido lato que yo le doy), a pesar del hecho de que siempre o casi siempre fue una minoría de la población libre (...) la que explotó el trabajo no libre a una escala significativa, y de que la mayoría - con frecuencia la gran mayoría- de los griegos (y romanos) libres eran campesinos que apenas utilizaban más que su propio trabajo y el de sus familias, de modo que vivían a un nivel no mucho más alto que el de la mera subsistencia".

54 G. E. M. de Ste. Croix, La lucha de clases.., pp. 70-1, señala que hasta el siglo IV d.C. los pequeños productores libres e independientes "debieron de constituir una mayoría efectiva de la población en casi todos los rincones del mundo griego (y romano) en todas las épocas, y asimismo debieron de ser los responsables de una parte sustancial del total de su producción - de hecho, de la mayor parte de ella, excepto en casos especiales, sobre todo en Italia durante el último siglo a.C., cuando se disponía de masas de esclavos 
clavos, presencia de una clase dominante que vive del excedente rural...) es probable que se viesen obligados a caracterizar también al mundo antiguo como feudal. De ese modo cuestiones añejas como la vía gentilicia al feudalismo cobrarían una luz renovada, y quizá podríamos descubrir las virtudes que Estrabón y la epigrafía vadiniense son capaces de ofrecer cuando se utilizan para comprender su propia época.

Pero dejemos las reducciones al absurdo. La clave está en determinar el papel que jugaban los esclavos no en el marco abstracto de la "sociedad altomedieval", sino dentro de las explotaciones aristocráticas ${ }^{55}$. Y aquí empiezan los problemas, porque ocurre que las zonas donde contamos con mayor número de testimonios acerca de la presencia de esclavos -Galicia, Asturias, El Bierzo, la Montaña leonesa- son también aquéllas que ofrecen más información acerca de las villae magnaticias. Aunque la cuenca leonesa del Duero es sin lugar a dudas la zona mejor documentada del reino de León para los siglos X-XI, la inmensa mayoría de los testimonios que ofrece son protagonizados por las élites locales de pequeños y medianos terratenientes, no por los monarcas o las grandes parentelas aristocráticas. Y no contamos para ella con fuentes como el Registro de Corias, ese inventario de los bienes del principal monasterio del occidente asturiano que todavía a comienzos del siglo XIII se preocupa por incluir cuidadosamente a los dependientes personales ${ }^{56}$, o el Liber Testamentorum de la catedral ovetense, que es en buena medida un muestrario de donaciones de grandes propiedades magnaticias.

Nuestra percepción sobre la presencia de los esclavos en la Asturias altomedieval se vería seriamente mermada si careciésemos de esas dos fuentes, y tenemos incluso la contraprueba: el fondo documental del monasterio de San Vicente de Oviedo, el único para la región asturiana en la Alta Edad Media que muestra un perfil social donde no predomina abrumadoramente la gran aristocracia y nos ofrece una ventana para asomarnos también en Asturias a ese mundo de notables locales semejante al que protagoniza buena parte de los testimonios sobre la cuenca leonesa del Duero. Pues bien, también aquí las menciones a esclavos o dependientes en general son escasísimas, y de hecho no aparecen antes de mediados del siglo XI, cuando el cenobio empieza a beneficiarse de donaciones aristocráticas ${ }^{57}$. El motivo de estas omisiones parece obvio: no sólo es

baratos, y, probablemente, en Atenas y en unas cuantas ciudades griegas más durante los siglos V y IV a.C., cuando también estaban muy baratos los esclavos-".

55 Tal es precisamente la postura adoptada en la única monografía sobre la Castilla condal que se toma en serio el problema de la esclavitud, y que precisamente por haber roto con las inercias de la investigación castellana no ha tenido la repercusión historiográfica que merece: Ernesto PASTOR DíAz de GARAYo, Castilla en el tránsito..., p. 281: "entendemos por "sociedad esclavista" aquella en la que la esclavitud era la forma dominante de utilizar la fuerza de trabajo ajena. Es decir, en la que el trabajo del esclavo era el recurso fundamental empleado por la aristocracia para poner en producción sus propiedades; en la que la posesión de esclavos procuraba, junto a otros factores, una hegemonía social que permitía acceder a la redistribución de rentas de marcado carácter político".

56 El redactor era plenamente consciente del valor de éstos. Como dice en el prólogo del códice: "neccessarium est unicuique ecclesie codicem habere bene notatum de ecclesiis, prediis, servis et possessionibus de iure sibi spectantibus" (RC, p. 43, f. 1rA7-10).

57 Las primeras menciones expresas (concretamente a mancipia y a creationibus) aparecen en dos documentos del año 1047 (SVO nos 41 y 42), sendas donaciones nada menos que de los condes Piniolo y Aldonza, 
que los magnates sean los grandes propietarios esclavistas, sino que aun cuando un pequeño o mediano terrateniente pudiese contar con algunos esclavos, serían para él comparativamente mucho más valiosos que para un aristócrata y estaría mucho menos dispuesto a desprenderse de ellos en una venta o donación ${ }^{58}$.

Con todo y con eso, parece innegable la existencia de una importante cesura social situada grosso modo entre los territorios situados al norte y al sur de la Cordillera. Incluso el fondo de San Vicente de Oviedo recoge alguna magna donación de esclavos del tipo que jamás encontraremos entre la documentación de Sahagún o la catedral de León $^{59}$, mientras que las donaciones de propiedades regias o aristocráticas en la cuenca leonesa del Duero pueden aludir genéricamente a los homines que habitan en las villas donadas $^{60}$, pero prácticamente nunca incluyen esas alusiones específicas a dependientes personales que son en cambio frecuentísimas en las entregas de bienes magnaticios en Asturias. Y si por ejemplo en el año 985 cierta Jimena hace una extensa donación a Sahagún, que afecta nada menos que a 17 villas, y sólo menciona a los esclavos de la única de ellas situada al norte de la Cordillera ${ }^{61}$; o todavía a la altura de 1099 ocurre lo mismo cuando, en una donación de tres cenobios menores al monasterio de Eslonza, la infanta Urraca sólo alude a los servis et ancillis del único que se localiza en Asturias ${ }^{62}$, debemos ver en ello algo más que una anécdota.

De modo que en Asturias la esclavitud parece haber jugado un papel de primer orden en la explotación de los dominios señoriales de la gran aristocracia laica, las principales

fundadores del monasterio de Corias. Evidentemente no computo el supuesto documento fundacional del siglo VIII (SVO $\left.\mathrm{n}^{\circ} 1\right)$, donde se alude a servos, ya que se trata de una refacción o falsificación de finales del siglo XII.

58 Tal parece ser el caso de SVO no 83 (1080), en que cierto García Suárez y sus hermanos hacen una donación piadosa de media villa en Llanera al monasterio de S. Vicente para cumplir la voluntad de su madre, pues una anotación al pie del documento se preocupa de especificar "foris illos omines". Como señala Élida García García, "Monasterios benedictinos y aristocracia laica en Asturias (siglos XI y XII)", Semana de historia del monacato cántabro-astur-leonés, ed. Monasterio de San Pelayo, Oviedo, 1982, p. 206, nota 59, lo más probable es que los donantes - que no parecen grandes aristócratas, sino más bien miembros de la nobleza local, al menos a tenor de las siguientes apariciones documentales de García Suárez como testigohayan exceptuado de la donación a los dependientes para así poder asentarlos en otra tierra de su propiedad y conservar su valiosa fuerza de trabajo. Y si sabemos de la existencia de los omines del presbítero Martín que trabajaban para él en sus propiedades, seguramente en Roces, junto a Oviedo -es probable pero no seguro que fuesen esclavos-, se debe al mero azar de que constituyeran el instrumento para que su amo se hiciese con nuevas tierras, ya que un hombre los hirió y tuvo que pagar una compensación ( $\mathrm{SVO}^{\circ}{ }^{\circ} 39$, año 1046). En cambio, cuando el presbítero donó más adelante sus bienes en Roces a S. Vicente (SVO, $\mathrm{n}^{\circ}$ 49, año 1054), se cuidó mucho de evitar mencionar a sus dependientes en la donación.

59 Singularmente la entrega de numerosos hombres de criazón que hizo el rey Alfonso VI en 1079 (SVOAdd $\left.\mathrm{n}^{\mathrm{o}} 1\right)$.

60 Vid. un listado de las concesiones de villas cum homines en el territorio de León (904-1037) en Juan José SÁnchez Badiola, El territorio de León en la Edad Media. Poblamiento, organización del espacio y estructura social (Siglos IX-XIII), ed. Universidad de León, León, 2004, vol. I, pp. 507-510.

${ }^{61}$ Sahagún $n^{\circ}$ 328. Se trata de la villa de Selorio, en el actual concejo de Villaviciosa; el resto se sitúan dentro del área leonesa.

62 Eslonza ${ }^{\circ} 71$. Se trata de los monasterios de S. Juan, en la propia ciudad de León; S. Adrián de Caldas, en la Montaña leonesa, concretamente en Boñar; y S. Juan de Berbío, en el valle del río Piloña (Asturias). 
instituciones eclesiásticas y por supuesto la propia monarquía (vid. Anexo, Tabla II). Y aunque parece probable que buena parte de los esclavos viviesen instalados en parcelas, lo cierto es que, lejos de disgregarse paulatinamente hasta desaparecer, la reserva señorial parece haber conservado su importancia a lo largo de todo el período altomedieval. Por ejemplo, todavía un diploma datable seguramente en el año 1063 mantiene con nitidez la distinción entre el «palacio» y las «ereditates» dentro del dominio ${ }^{63}$. Lo que es más, el texto nos ha llegado sólo en refacciones -para algunos autores serían en realidad falsificaciones- de comienzos del siglo XII, así que si la expresión datase en realidad de esta época y no del reinado de Fernando I el testimonio sería todavía más interesante como muestra de perduración de los viejos esquemas dominicales.

De hecho, y a pesar de lo que se ha venido afirmando habitualmente acerca de la falta de testimonios en el noroeste peninsular relativos al "modelo bipartito" clásico, en el que los cultivadores de las parcelas prestan servicios de trabajo en la reserva, al menos para Asturias hay indicios claros en ese sentido. Uno de los más evidentes es el de la dotación fundacional de Corias por los condes Piniolo y Aldonza en $1044^{64}$, donde establecen que los servi deben trabajar para el monasterio dos días por semana. Por comparación con otras zonas, se ha entendido incluso que ésta era una situación anómala, con unas exigencias en trabajo excepcionalmente duras ${ }^{65}$.

Y sin embargo, no se ha reparado en que el documento afirma exactamente lo contrario: los magnates fundadores parecen plantear esta regulación como una liberación, como si lo natural fuese que los dependientes trabajasen seis días a la semana para el amo (respetando, eso sí, el descanso dominical), y ellos en cambio aprovechasen el acto piadoso de la fundación de un monasterio para mostrarse también caritativos con los esclavos y reducir notablemente su carga laboral. De ahí que, en una cláusula de otro modo chocante, esos cuatro días semanales de trabajo de los servi por cuenta propia sean presentados por los condes exactamente en los términos de una donación piadosa: «et alios quatuor dies laborent quod voluerint pro animabus nostris». La conclusión se impone: los fundadores de Corias no están concediendo una suerte de "fuero agrario" a unos colonos para regular el tipo de prestaciones que deben al monasterio a cambio de cultivar sus parcelas; están proponiéndose como modelos de piedad al planificar una explotación esclavista especialmente benévola.

\footnotetext{
63 Miguel Calleja Puerta, "Refacciones de un diploma de Fernando I en la catedral de Oviedo", Alma littera. Estudios dedicados al profesor José Manuel Ruiz Asencio, Marta Herrero de la Fuente et alii (eds.), ed. Universidad de Valladolid, Valladolid, 2014, p. 94: "et qui irruptionaem fecerit in palacio vel in ereditate Sancti Salvatoris..." (se trata de una copia o refacción). Todavía conserva dicha dicotomía, limitándose a hacer correcciones estilísticas en la frase, una refundición coetánea que a su vez sirvió de fuente a la versión del Liber Testamentorum: "et qui inruptionem fecerit in palatio vel in hereditatibus Sancti Salvatoris..." (LTO no 33). Vid. Miguel Calleja Puerta, "Refacciones de un diploma de Fernando I...", para el estudio detenido de la tradición documental.

${ }^{64}$ RC, pp. $48-51$ (f. 3vB-5rB).

65 Élida García García, San Juan Bautista de Corias. Historia de un señorío monástico asturiano (siglos $X-X V)$, ed. Universidad de Oviedo, Oviedo, 1980, p. 220.
} 
Ello quiere decir que a mediados del siglo XI lo habitual en los dominios aristocráticos asturianos debía de ser el mantenimiento de una importante reserva señorial, en la que la explotación directa con mano de obra esclava jugaba todavía un gran papel ${ }^{66}$. De hecho, es probable que -al menos allá donde los dueños no se planteasen realizar grandes exhibiciones de misericordia- muchos servi tuviesen que estar aún disponibles a discreción de su propietario, lejos de llevar una arraigada existencia equiparable a la de los arrendatarios libres ${ }^{67}$. Eso explicaría tanto la recurrente presencia de los dependientes personales en la documentación magnaticia relativa a la región para la segunda mitad del siglo XI como la facilidad que parecen tener los amos para trasladar a sus esclavos de una propiedad a otra. Los testimonios al respecto son elocuentes: por ejemplo, un documento del Liber Testamentorum de c. 1090 relata cómo dos generaciones antes cierto Valerio, calificado de «cellararius monasterii $\rangle^{68}$, fue llevado desde Grandas de Salime «pro servitiale» a Corendenio (probablemente Corondeño, en Allande) ${ }^{69}$; mientras que el Registro de Corias señala que en algún momento del siglo XI don Vermudo de Cibuyo instaló a algunos esclavos en su villa de Abanceña (Cangas del Narcea) ${ }^{70}$. También en un documento de 1079 doña Enderquina García relata cómo junto a su marido Martín Vermúdez $^{71}$ había trasladado ciertas familias desde la villa de Felgarinas $^{72}$, que perte-

\footnotetext{
${ }_{66}$ Todavía en 1164 los condes Pedro Alfonso y María Froilaz, que unos años atrás habían fundado el monasterio de Lapedo (Belmonte) en el occidente de Asturias, establecen que la relación del cenobio con los cultivadores que se instalan en su terreno ha de basarse en la exigencia no de rentas-apenas se requiere de ellos un simbólico censo anual de 1 sueldo -sino de importantes prestaciones laborales: cada solar debe aportar semanalmente dos jornadas de trabajo, así como dos hombres durante 15 días en la época de la cosecha: Élida García GarCíA, "Concesiones agrarias en Asturias (siglos XI y XII)", Asturiensia Medievalia, 6 (1991), pp. 133-134. Así que aún en la segunda mitad del siglo XII la reserva señorial seguía teniendo una enorme importancia en los dominios aristocráticos de la zona y permanecía vigente el viejo esquema del "modelo bipartito".

67 Vid. infra el apartado sobre el declive de la esclavitud para ejemplos de este tipo de exigencias a dependientes personales en el occidente de Asturias todavía en los siglos XII-XIII.

68 Dado el contexto, hay que entender la expresión como "trabajador asociado a la reserva", no como "cillerero" en el sentido de monje despensero (aunque tampoco cabe descartar la idea de un administrador servil, al estilo de los sergents franceses). De hecho, en la Asturias bajomedieval el término çellero tiene claramente el significado de centro de administración y explotación señorial: Soledad SUÁREZ BELTRÁN, $E l$ cabildo de la catedral de Oviedo en la Edad Media, ed. Universidad de Oviedo, Oviedo, 1986, pp. 88-90; Juan Ignacio RUIZ DE LA PEÑA SOLAR y Soledad BELTRÁN SUÁREZ, Señorío y vasallaje en la Asturias medieval: el Libro de las Jurisdicciones de la Mitra ovetense (1385-1386), vol. I: Introducción. Edición crítica. Índice toponímico, ed. Real Instituto de Estudios Asturianos, Oviedo, 2009, p. 81; mostrándose así como una traducción bastante exacta del palatium altomedieval, cuyo estudio de referencia sigue siendo José Ángel GARCÍA DE CORTÁZAR y Esther PEÑA BOCOS, "El palatium, símbolo y centro de poder en los reinos de Navarra y Castilla en los siglos X a XII", Mayurqa, 22 (1989), pp. 281-296.

${ }^{69}$ LTO $\mathrm{n}^{\circ} 46$.

70 "populauit eam de nouo de suis seruis" (RC, p. 61; fol. 10rA18-22). No da la fecha de la población, pero tuvo que producirse en la undécima centuria, pues esa misma noticia indica que en 1112 los nietos del fundador vendieron la villa al monasterio de Corias.

${ }^{71} \mathrm{Su}$ condición de propietarios esclavistas queda patente también en el documento en que manumiten en 1072 a una familia de ocho "mancipios" -un matrimonio con sus cinco hijos y el hermano de la mujer-que Martín Vermúdez había heredado de sus padres don Vermudo y doña Palla (CCO n 68).

72 Seguramente Folguerinas (Salas), pues Martín Vermúdez tenía bienes en la zona: LTO nº 58 (1069).
} 
necía a su esposo, hasta la de Guyame (Llanera) ${ }^{73}$. Así mismo, una noticia sin fecha del fondo de Otero de las Dueñas, posiblemente del primer tercio del siglo XII -aunque relata hechos del pasado, muy probablemente del reinado de Alfonso VI- y referida a las villas asturianas de Llaneces y Sorribas (ambas en Lena), presenta como algo natural el desplazamiento de las gentes de criacione a voluntad de su amo: cuando un conde se hace con la villa de Llaneces traslada allí a un matrimonio de hombres de su criazón para ejercer de caseros, y también se trae consigo a diversos dependientes personales desde el Bierzo a la villa de Sorribas, desplazándolos como mínimo unos $100 \mathrm{~km}^{74}$. Del mismo modo, el Registro de Corias recoge cómo en algún momento de la segunda mitad del siglo XI o de los primeros años del XII el abad Munio sacó a dos esclavos de Ansarás (Tineo) para instalarlos en la villa de Forcinas (Pravia), sita a unos $40 \mathrm{~km}^{75}$. En cambio, en la cuenca leonesa del Duero la presencia de la esclavitud de tipo productivo parece haber sido mucho menos significativa (baste comparar en el Anexo las Tablas I y II ${ }^{76}$. Diversos autores han señalado la escasez de menciones en los textos altomedievales de la región ${ }^{77}$, pero desde mi punto de vista tiene aún mayor valor explicativo una contraprueba de carácter retrospectivo: al revisar la documentación de la zona para los siglos XI-XIII no encontraremos referencias a la presencia masiva en los dominios aristocráticos de grandes grupos de criazones u otro tipo de dependientes personales que puedan estar mostrando la pervivencia de antiguas formas de explotación esclavista, tal y como ocurre en Asturias o Galicia en esas mismas fechas. Incluso dentro del ámbito leonés, con una tipología de fuentes bastante homogénea, llama la atención la singularidad que ofrecen dos zonas: el Bierzo y la Montaña, que estando mucho peor documentadas que la Meseta acaparan sin embargo gran parte de los testimonios relativos a esclavos en las colecciones diplomáticas conservadas (vid. Anexo, Tabla I).

Parece lógico pensar que en la Meseta leonesa la desestructuración de las estructuras tradicionales de poder magnaticio en los siglos VIII-IX y la pujanza de la colonización campesina -por ejemplo en espacios como el Páramo o los Oteros, tierras de roturación

\footnotetext{
73 "Dono aliam uillam in Planera de Oueto, uocata Buliamne (...) cum sua familia, quam adduximus de hereditates de uiro meo et genitores eius de villa Felgarinas" (LTO no 55). Soledad BeLtrÁn SuÁREz, "El concejo de Llanera en la Tardoantigüedad y la Alta Edad Media", Perxuraos. Revista cultural de Llanera, 1 (2012), p. 20, comenta el caso dentro de una interesante reflexión sobre la dependencia personal en la Asturias de los siglos XI-XII.

74 Ambas referencias en Otero n 304: "e metiuit illo comite in Flaneces suo casero, per nomen Seruando Petriz, et Maria Fernandiz, muliere de Seruando, filia de Fernado Guteriz et ambos criacione de illo comite (...) Et in illa de Soribas fuit de suo auolengo de illo comite, et quando se ueno illo comite de Berizo aduxo cunsigo sua criacione, pernominnados Aznar et Çanel et $I^{a}$ mora, Iouida, sua lauadera, et alia multa criacione". 75 RC, p. 143 (fol. 63rA14-17). La noticia no está fechada, pero el abad Munio ejerció el cargo en el período 1063-1118: Élida García García, San Juan Bautista de Corias..., p. 91.

76 Ya Claudio SÁnchez-Albornoz, "Los siervos en el noroeste hispano...”, p. 1.606, oponía en este sentido el valle del Duero a las tierras de Galicia y Asturias.

77 José Ma Mínguez Fernández, El dominio del monasterio de Sahagún en el siglo X. Paisajes agrarios, producción y expansión económica, ed. Universidad de Salamanca, Salamanca, 1980, pp. 89-90; Pascual Martínez Sopena, La Tierra de Campos Campos occidental. Poblamiento, poder y comunidad del siglo X al XIII, ed. Diputación Provincial de Valladolid, Valladolid, 1985, pp. 215 y 239; Carlos de Ayala Martínez, "Relaciones de propiedad...”, pp. 192-199; Juan José SÁnchez BADIOLA, El territorio de León..., vol. I, p. 494.
} 
que a la larga acabarían casi completamente señorializadas- obligaron a la aristocracia altomedieval a reconstruir su dominación sobre bases nuevas, a partir de la sujeción de las comunidades campesinas autónomas ${ }^{78}$ y la patrimonialización de los derechos y jurisdicciones de naturaleza pública sobre los hombres libres ${ }^{79}$. Así, si en los espacios situados al norte de la Cordillera Cantábrica -así como en la Montaña leonesa y especialmente en el Bierzo, donde la ruptura social también parece haber sido menor- la vigencia del modelo esclavista permitía a los grupos magnaticios combinar en su beneficio viejas y nuevas formas de explotación, en los dominios aristocráticos de la cuenca leonesa del Duero estas últimas debieron de jugar un papel mucho mayor.

Ello no quiere decir que el esclavismo fuese meramente anecdótico en la región ${ }^{80}, \mathrm{ni}$ que el sometimiento de los campesinos se produjese con mayor fuerza o rapidez que en Asturias. Para la Meseta leonesa habría que pensar más bien en un dominio aristocrático sobre el territorio más débil y menos tupido, lo que implicaría la existencia en la Alta Edad Media de unas explotaciones magnaticias que en comparación con sus homólogas norteñas serían más pequeñas y menos compactas, dependerían más de los arrendatarios libres y de relaciones de dominación todavía incipientes -como la progresiva sujeción de los homines de mandatione o el desarrollo de formas de dependencia asociadas a la tierra- y contarían con un menor protagonismo de figuras de vieja raigambre como la reserva señorial, la explotación directa o la mano de obra esclava.

Aunque éstas por supuesto seguían existiendo con una importancia algo más que "residual": baste pensar en las opera que tienen que realizar -sin duda en la reserva- los habitantes de la villa de San Víctor (en principio nada indica que fuesen esclavos, sino que estamos probablemente ante un caso de "modelo bipartito") que fue donada por Ramiro III al monasterio de San Cipriano de Rueda ${ }^{81}$, en las disposiciones del Fuero de León que no dejan lugar a dudas sobre la existencia de esclavos, o en los homines de palatio que aparecen en Tierra de Campos todavía en el siglo XIII asociados a la explotación directa de reservas señoriales ${ }^{82}$.

\footnotetext{
78 El trabajo clásico sobre el tema es Reyna PAStor DE Togneri, Resistencias y luchas campesinas en la época del crecimiento y consolidación de la formación feudal. Castilla y León, siglos X-XIII, ed. Siglo XXI, Madrid, $1993^{3}$.

79 Claudio SÁnchez-Albornoz dedicó un detenido estudio a dicho proceso: "Homines mandationis y iuniores", publicado originalmente en Cuadernos de Historia de España, 53-54 (1971), pp. 7-235. La importancia historiográfica de este trabajo inmerecidamente relegado es señalada en Juan José LARREA, "Villa Matanza", Les sociétés méridionales à l'âge féodal (Espagne, Italie et sud de la France Xe-XIII ${ }^{e}$.). Hommage à Pierre Bonnassie, textos reunidos por Hélène Débax, ed. C.N.R.S. - Université de Toulouse-Le Mirail, Toulouse, 1999, p. 227.

${ }_{80}$ Recordemos las particularidades documentales ya señaladas, que obligan a relativizar en cierta medida los argumentos ex silentio. Una cosa es reconocer el hecho evidente de que la esclavitud tenía mucha mayor importancia en los territorios norteños, y otra muy distinta suponer que en las explotaciones señoriales de la Meseta era una realidad meramente residual o marginal.

81 CCL no 461 (978). Comenta el caso Carlos de Ayala Martínez, "Relaciones de propiedad...", p. 216, quien considera que esas opera consistían "obviamente en trabajos gratuitos en la "reserva" señorial".

82 Pascual Martínez Sopena, La Tierra de Campos occidental..., pp. 239, 241, 466, 478-479 y 567-568. Carlos de Ayala Martínez, "El yuguero...", p. 27, nota 37, señala que a veces esos homines de palatio son calificados precisamente como omnes de criazón, por ejemplo todavía en un documento de 1240 del fondo del monasterio de S. Zoilo de Carrión.
} 


\section{Un declive tardío}

En un proceso muy mal conocido, durante la Plena Edad Media la esclavitud productiva y los estrechos vínculos de dependencia personal asociados a ella acabaron por desaparecer de la región asturleonesa. En la Meseta leonesa su extinción no produce excesiva sorpresa, pues pudo producirse mediante un mero declive gradual de una forma de explotación que seguramente nunca había sido predominante en los dominios señoriales, pero el caso resulta más paradójico en Asturias, donde la institución de los homines de criatione pervive aún con fuerza en fechas tardías. Como ya hemos visto, todavía en 1172 unos hombres calificados de criacione son vendidos al monasterio de Lapedo (Belmonte) a cambio de diversas cabezas de ganado valoradas en un total de 468 maravedís $^{83}$, y la dependencia personal sigue estando muy extendida a comienzos del siglo XIII, tal y como atestiguan las delimitaciones de propiedades realengas ordenadas por Alfonso IX en la zona ${ }^{84}$ o las extensas nóminas de dependientes personales recogidas en el Registro de Corias $^{85}$.

Sería tentador ver en ello un rasgo original del occidente asturiano, de no ser porque, aunque para la Asturias central ${ }^{86}$ no hemos conservado las pesquisas de Alfonso IX ni contamos con ningún inventario señorial de comienzos del siglo XIII, los hombres de criazón aparecen bien documentados a lo largo del siglo XII, y todavía en 1200 el rey Alfonso IX incluye en la dotación fundacional del monasterio de Valdediós (Villaviciosa) a los piscatores y serviciales de la heredad de Boiges $^{87}$; mientras que en ese mismo año, al ingresar como monje en el monasterio de San Vicente de Oviedo, cierto Fernando Martínez - conocido como Garvixo- hace partición con sus parientes de sus criaciones en el valle de Candamo ${ }^{88}$.

Lo razonable sería pensar que a esas alturas la situación social ha evolucionado y la condición de estas criazones sería no tanto la de esclavos como la de siervos personales: personas que siguen sujetas a una dependencia estrecha de su señor que les viene dada de nacimiento y llevan «pegada a los huesos» independientemente de que trabajen o no las tierras de aquél; esta mácula servil les impone diversas cargas y obligaciones con respecto a su señor (el cual sigue por cierto pudiendo enajenar sus derechos sobre

\footnotetext{
83 Belmonte $\mathrm{n}^{\circ} 75$.

84 Sólo se han conservado fragmentariamente, por ejemplo en el acta de división de hereditates et criaciones con el monasterio de Lapedo (Belmonte): Belmonte $\mathrm{n}^{\circ} 105$ (1216); o con el de Corias (aunque el Registro coriense se resiste a incluir un término tan vulgar como el de criazones y habla meramente de homines): RC, pp. 188ss (1214) y pp. 210-1 (1228).

85 Élida García García, San Juan Bautista de Corias..., pp. 217-229, destaca la importancia de la población servil en los dominios del monasterio. En el inventario de bienes del cenobio elaborado en el primer tercio del siglo XIII son frecuentes las nóminas de dependientes personales, encabezadas por la entradilla De servis (RC, pp. 55, 56, 57, 64, etc.).

86 El oriente asturiano es un caso aparte por su parquedad documental para gran parte del período medieval. 87 Julio González, Alfonso IX, vol. II: Colección diplomática, Madrid, Instituto Jerónimo Zurita, 1944, doc. $\mathrm{n}^{\circ}$ 143. Esta terminología es habitual en los registros de dependientes personales, como LTO $\mathrm{n}^{\circ} 14 \mathrm{o}$ RC, p. 127, fol. 54vB15-16.

88 SVO no 369 (1200).
} 
ellos), pero ya no están obligados a proporcionarle toda la fuerza de trabajo que éste solicite, ni sujetos a separaciones familiares, desarraigos ni desplazamientos forzosos ${ }^{89}$. Algo así parece estar indicándonos el Registro de Corias cuando utiliza el pago de nuncios, infurciones y pedidos (petitiones) como signo de identidad personal servil ${ }^{10}$, lo que recuerda a los siervos personales franceses, que también eran identificados por estar sujetos a imposiciones determinadas (en su caso el chevage, el formariage y la mainmorte $\left.{ }^{91}\right)$. Y desde luego la historia que recoge acerca del robo del cadáver de cierto Martín Gacesa, servus del monasterio de Bárcena (dependiente de Corias) que murió sin hijos y entregó a dicho cenobio su heredad en Miño (Tineo) para enterrarse en él, no está hablándonos de un esclavo92.

Y sin embargo, las cosas no son tan sencillas. Lejos de haberse producido una unificación en el estatuto de los dependientes en torno a la convencional "servidumbre" o una mejora global en la situación de los homines de creatione, en la práctica las condiciones de existencia de los dependientes personales de la Plena Edad Media debían de ser enormemente diversas (dejando a un lado por supuesto la esclavitud doméstica, que no interesa aquí). Para empezar, la condición de muchos antiguos dependientes de otro tipo se había degradado hasta situarlos en una situación bastante parecida a la de las criazones. Por ejemplo, la de los viejos homines de mandatione, antiguos libres que habían quedado reducidos a la condición de meros dependientes personales: el Registro de Corias los equipara a todos los efectos con los servi ${ }^{93}$.

89 Es el grupo social al que, en el ámbito de la Francia del Languedoïl, Marc BLoch dedicó tantos hermosos estudios: vid. supra nota 7.

90 Por ejemplo en RC, p. 129 se registra que el conde Sancho, hermano del fundador, había donado a Corias ciertos servi en la villa de Cabanella (Navia) "et debent dare nuncios ad mortem suam et in vita sua offorciones et petitiones et alia servicia" (f. 56rA2-12); e íbidem, p. 130, señala que en Teifaros (Navia) "habet Coriensis ecclesia homines de servicio cum sua hereditate, qui sunt de nuncio et de offortione et de petitione" (fol. 56rB24-27).

91 Marc Bloch, Reyes y siervos..., pp. 40-56.

92 RC, pp. 177-178 (fol. 80rA10-B14).

93 Élida García García, San Juan Bautista de Corias..., p. 219. Aunque en su hermoso estudio Claudio SÁnchez-Albornoz, "Homines mandationis...", pp. 575-576, supuso -por la propia lógica que imponía su originaria condición de propietarios- que los hombres de mandación acabaron convertidos en iuniores per hereditatem, lo cierto es que en el inventario coriense aparecen distribuidos en casadas familiares, igual que el resto de servi, lo que deja clara su condición de dependientes personales (también en casatas se distribuyen los dependientes personales de la catedral de Oviedo a comienzos del siglo XII: LTO ${ }^{\text {os }} 11$ y 14). $Y$ de hecho se diferencian expresamente de los sujetos a dependencia por la mera tenencia de tierras, de los cuales no se da el nombre, sino que el énfasis se pone en la cuantía de la renta debida. Vid. por ejemplo el epígrafe De servis relativo a Perpera (Cangas del Narcea) en RC, p. 57, fol. 8vA1-14: "In Perpera istas casadas sunt de mandatione: in Pennas casata de Fernando Diez, de Gondesendo, de Godesteo, de Nepociano. In Villare casata de Pantone et de Cantonio. In Rebolles casata de Dominico Pelaiz. In Soianes casada de Cantezo, de Santo, de Monio Iustiz. In Rebolles uno solare de X solidos et alium in Verganne. Ilii alii heredes de Perpera sunt de VI quarteros. In Rovredo casada de Pegano de mandatione". No estamos por tanto ante esa convención de la "igualación de estatutos de libres y esclavos en un término intermedio", sino ante un ejemplo de degradación absoluta de la condición de un grupo social originariamente libre. 
O los sujetos a la antigua encomendación (maulatum), que ya a comienzos del siglo XII no parecen tener un género de vida muy distinto de los hombres de criazón contemporáneos. Al menos eso es lo que se deduce de las condiciones en las que cierto Pedro Domínguez - probablemente habitante de Niembro (Gozón), donde se otorga el documento - entra en dependencia personal como homo sine alio domno de San Vicente de Oviedo en el año 1135, por casarse con una mallada (es decir, maulata, sometida a maulatum) del monasterio, y parece que asume las condiciones propias del estatus de su mujer ${ }^{94}$. Pues bien, se compromete a hacer servitium a San Vicente «in piscatione vel quomodo vobis placuerit», quedando sujeto ya de por vida a su dominio, sin posibilidad de romper el lazo huyendo o abandonando a su esposa ${ }^{95}$. La naturaleza de su dependencia personal estricta, como trabajador adscrito al cenobio que es alimentado por éste -igual que cualquier hombre de criazón cuando es llamado a servicio- queda de manifiesto en una nota dorsal del documento donde figura como receptor de raciones en cereal ${ }^{96}$. Por otro lado, probablemente muchos descendientes de antiguos esclavos consiguieron adquirir en época plenomedieval ese estatus de siervos personales que apenas los diferenciaba del resto de campesinos dependientes más que por el hecho de estar sujetos al pago de determinados tributos especiales. Pero el mismo Registro de Corias nos informa de que, para otros, todavía a comienzos del siglo XIII seguía vigente la obligación de prestar indiscriminadamente su fuerza de trabajo al señor. La fuerza del arcaísmo es tan grande que, como si el reloj de la Historia se hubiera detenido en algún momento del siglo IX, la noticia relativa a la villa de Abanceña (Cangas del Narcea) en el inventario coriense incluye una fórmula sobre los dependientes personales que recuerda mucho a las utilizadas en los polípticos carolingios: «ibi sunt pumareros de Corias, carregadores, vakeros, caseros et quicquid eis mandaverint facere» ${ }^{97}$.

\footnotetext{
94 La norma visigoda para los matrimonios entre libres y esclavos era que el cónyuge ingenuo perdiese su libertad, pero en época del reino asturleonés parece que el esposo libre de una esclava conservaba su condición ingenua (aunque debía labrar la heredad de su mujer) y podía abandonar a su esposa cuando quisiera: Claudio Sánchez-Albornoz, "Los siervos en el noroeste...", p. 1584. Las condiciones en las que se somete Pedro Domínguez a San Vicente recuerdan más bien al primer caso, como veremos inmediatamente.

95 SVO n 191 (1135): "Ego Petrus Dominiquiz fatio placitum de me ad Sanctum Vincentium et vobis abbas domno Petro, ut sim vester homo sine alio domno, et fatiam vestrum servitium in piscatione vel quomodo vobis placuerit; pro que datis michi vestra mallada, nomine Eulalia, pro muliere legitima; et si illa mulier vivente ego laxare eam voluero sine culpa de concilio, vel de vestro servitio exire voluero, licentiam abeatis super me sicut in vestro homine ubicumque fuero, et sim periurus et excomunicatus".

96 SVO no 191 (1135): "Noticia de pane que despeso illo abbate. In novembrio dio I de scandola et emina, et tercias que dedit ad Ecta Martiniz; II kexas (?) de scandola et alia II de ordio ad Petro Domenquiz; una de scandola et alia de ordio et sestero pro illa pallia".

97 RC, p. 61. En el "políptico de Irminón" aparecen con frecuencia fórmulas del tipo "ubi/quantum ei injungitur/jubetur" para referirse a las labores de los trabajadores dependientes: Auguste LongNon, Polyptyque de l'abbaye de Saint-Germain des Prés rédigé au temps de l'abbé Irminon, tome II: Texte du polyptyque, ed. H. Champion, Paris, 1886-1895 (sic), pp. 3, 4, 5, 8, 30, 35, 41, 44, 48, 52, 56, 59, 66, etc. En pp. 138 y 166 encontramos incluso una expresión prácticamente idéntica a la del registro coriense: "et (omnia) quicquid eis injungitur".
} 
De hecho, ya en la centuria anterior el refactor de la supuesta escritura fundacional del monasterio de Obona, también en el occidente de Asturias, había incluido una cláusula relativa a las criazones en la que utilizaba un verbo muy caro al abad Irminón: «Et isti serviant monasterio Sanctae Mariae de Obona in quantum et quale servitium ab abbati vel vicario huius monasterii eos vocaberint vel iniungerint». El documento está todavía redactado en pleno siglo XII ${ }^{98}$ por una mentalidad esclavista, en la que los hombres de criazón son instalados allá donde el abad o su vicario decide y pueden ser llamados para trabajar en la reserva cualquier día -sin limitación temporal alguna al estilo de las dos jornadas semanales que establecía la dotación fundacional de Corias- o incluso requeridos como domésticos en el propio monasterio ${ }^{99}$. Desde luego, no todos los amos tenían las inquietudes piadosas de Aldonza y Piniolo.

A pesar de su perduración -en condiciones de sujeción más o menos estrecha- hasta comienzos del siglo XIII, estos dependientes personales desaparecen en adelante de nuestra documentación incluso en el occidente de Asturias. Ni siquiera la documentación coriense posterior al Registro vuelve a ofrecer noticias sobre este grupo social, tan

\footnotetext{
98 La tradición documental de este diploma (por lo demás, hoy perdido) es muy compleja, aunque la versión que conocemos es sin duda una refacción o falsificación tardía. Lo más probable es que un documento auténtico de donación otorgado por Adelgáster a finales del s. X o comienzos del XI (de hecho un Algaster es mencionado en Corias, p. 154, fol. 68vA13 como contemporáneo del infante Ordoño Vermúdez, quien está documentado en los años 1001-1042: Margarita Torres SeVILla-QuiÑones De León, Linajes nobiliarios de León y Castilla (Siglos IX-XIII), ed. Junta de Castilla y León, Valladolid, 1999, pp. 116-7) fuese rehecho para adelantar su fecha dos siglos y hacer pasar al donante por un infante, supuesto hijo del rey Silo; pero además este "primer falso" (s. XII?) fue a su vez objeto de nuevas interpolaciones y manipulaciones a lo largo de los siglos. Antonio C. Floriano Cumbreño, Diplomática española del período astur. Estudio de las fuentes documentales del reino de Asturias (718-910), ed. Instituto de Estudios Asturianos, Oviedo, 1949, vol. I, p. 77, identifica en el documento estratos de los siglos XII, XIII y XVI (cuando tuvo lugar la refacción erudita que dio forma definitiva al diploma falso que conocemos), añadidos sobre el originario texto altomedieval. Miguel Calleja Puerta, El conde Suero Vermúdez..., p. 431, cree probable que el falso fundacional se forjara en el s. XII, y a esa fecha lo atribuye también Élida García García, "Concesiones agrarias en Asturias...", p. 135, quien afirma que "estos datos relativos a las criazones pueden considerarse auténticos si los referimos a esta centuria". Cuestión diferente es la propia nómina personal de criazones, que muy probablemente se remite a la donación original de finales del s. X o comienzos del XI, pues casa bien con el tenor habitual en los documentos de dicha época. No así la regulación de sus condiciones laborales, que sería una rareza antes de mediados del s. XI y debemos atribuir a una interpolación seguramente incorporada en la refacción del s. XII. Así que en el original debía constar tan sólo la lista nominal de dependientes dentro del conjunto de bienes incluidos en la dotación fundacional, y de hecho, en la versión que conocemos las huellas de la interpolación son evidentes, pues tras las cláusulas laborales, penales y de prohibición de servicio a otro señor, se retoma la enumeración de bienes muebles: "Damus siquidem in ipsa domus Dei viginti vacas et quinque iuga boum...".

99 Obona $\mathrm{n}^{\mathrm{o}}$ 1: "Damus siquidem nostras criationes nominatas (...) Et isti serviant monasterio Sanctae Mariae de Obona in quantum et quale servitium ab abbati vel vicario huius monasterii eos vocaberint vel iniungerint. Et habeant illa hereditate de Perella et prestimonia in hereditate Sanctae Mariae, ubi abbas monasterii huius et eius vicario dederit. Et in die qua vocati ad servitium fuerint, habeant portionem edendi et bibendi, scilicet libra una, et quarta panis milli vel de alio segundo, et portionem fabae et milli vel de alia edulia, et sicerae, si potest esse. Et si in monasterio assiduitas fuerit serviendi, habeant predictam portionem victualis et vestimentum sicut ipsa domus Dei sufferre potuerit".
} 
abundante aún cuando se realizó el inventario ${ }^{100}$. Su aparentemente repentina desaparición sigue siendo un enigma. Podríamos estar en parte ante un problema de fuentes, pues precisamente a partir de esta época se rarifica la tipología documental más propensa a informarnos sobre este tipo de dependientes: con posterioridad a Alfonso IX ya no tendremos grandes enajenaciones o delimitaciones de propiedades regias, y tardaremos mucho en volver a contar con inventarios de bienes señoriales al estilo de los incluidos en el Liber Testamentorum o, mucho más sistemáticamente, en el Registro de Corias.

El siguiente para Asturias es ya el Libro de las Jurisdicciones, un inventario de bienes, derechos y rentas pertenecientes al obispo de Oviedo, elaborado a finales del siglo XIV y donde nos encontramos ya un panorama de "servidumbre" territorial clásica, con vasallos sometidos al pago de tributos anuales y una terna ideal -sujeta a variantes locales- de vodos, nunçios e manerías que se exigen, fundamentalmente en los cotos episcopales, a quienes trabajan tierras de la Iglesia ${ }^{101}$. Quedan eso sí algunos residuos o huellas del modelo antiguo, como esos moradores en el coto de Cerdeño (Oviedo) que junto a un censo anual en dinero «han de fazer las otras cosas que lles mandar el mayordomo del palaçio del obispo» o ese pago de 20 sueldos al año con el que los vasallos de Santo Adriano se redimen «de toda fazendera e de toda otra demanda» ${ }^{102}$. Pero en todos los casos la dependencia parece venir dada exclusivamente por estar sometidos al señorío jurisdiccional (vasallos) y/o territorial (foreros) del obispo, sin rastro de lazos específicamente personales. Y ese mismo panorama parecen ofrecer los inventarios bajomedievales de bienes y derechos en el Tumbo Viejo del monasterio berciano de San Pedro de Montes ${ }^{103}$.

De modo que en algún momento entre el primer tercio del siglo XIII y finales del siglo XIV -muy probablemente más cerca de la primera que de la segunda fecha- tuvo lugar la desaparición de toda forma de dependencia personal en la región. El problema sigue pues abierto y requeriría de un estudio específico, por ejemplo a partir de esas cláusulas que aparecen en los contratos agrarios del siglo XIII sobre la obligación de "poblar" las heredades con homines ${ }^{104}$. Posiblemente el factor fundamental fue el desarrollo de la economía monetaria y de mercado, cuya implantación es muy evidente en Asturias durante la decimotercera centuria, llegando a modificar completamente el panorama social y económico con respecto a la época anterior. Esta nueva situación debió de ir haciendo cada vez más anacrónicas y poco rentables figuras como las pequeñas industrias señoriales de artesanos serviles o la manutención directa de trabajadores rurales más allá de unos pocos días al año, en momentos de especial intensidad laboral.

\footnotetext{
100 Élida García García, San Juan Bautista de Corias..., pp. 224-225.

101 Juan Ignacio Ruiz de la Peña Solar y Soledad beltrán suárez, Señorío y vasallaje..., pp. 74-75.

102 Juan Ignacio Ruiz de la Peña Solar y Soledad beltrán suárez, Señorío y vasallaje..., respectivamente en p. 126 y p. 138.

103 Vid. TVM, $2^{\mathrm{a}}$ y $3^{\mathrm{a}}$ parte.

104 Por ejemplo, Ma Josefa Sanz Fuentes y Juan Ignacio Ruiz de la Peña Solar, Colección diplomática del monasterio de San Vicente de Oviedo (1201-1230), ed. Imprenta Gofer, Oviedo, 1991, doc. $\mathrm{n}^{\mathrm{o}} 12$ (1207): "et populemus eam de homine et tectis".
} 
No obstante, eso sólo explicaría la desaparición de las formas más estrechas de dependencia personal, vinculadas a la economía servil. Pero parece que lo lógico hubiera sido que el conjunto de los hombres de criazón y similares acabasen convertidos en meros siervos personales sujetos al pago de derechos específicos, como ocurría en Francia. Y sin embargo, no fue así en Asturias, donde también los siervos personales se esfumaron. Quizá porque los equivalentes de las cargas específicamente serviles en el país galo (formariage y mainmorte; siendo el chevage un mero censo anual asimilable a cualquier otro), es decir, el vodo, el nuncio y la mañería, cobraron en el país asturiano un carácter jurisdiccional o territorial. A partir de ese momento ya no tendría sentido por ejemplo señalar -como hemos visto que todavía hacía el Registro de Corias- el pago de nuncios o infurciones como signo que identificaba sólo a determinados habitantes del señorío. Como resultado, los siervos personales perdieron el principal rasgo específico que podría diferenciarlos dentro del conjunto de campesinos dependientes, quedando sujetos ya a particularismos menores.

Finalmente, debió de jugar también su papel la política regia de fundación de polas de estatuto privilegiado en Asturias a lo largo del siglo XIII ${ }^{105}$, pues en principio serían precisamente los siervos personales los más atraídos por las promesas de igualación jurídica que ofrecían estas nuevas comunidades. Ello pudo animar a los señores, ya desinteresados de la dependencia personal como factor productivo, a dejar de insistir en las particularidades más bien simbólicas -algún censo adicional, alguna restricción o tradición más o menos humillante- que pudieran seguir caracterizando específicamente la condición servil a esas alturas.

\section{Conclusiones}

La relegación de la esclavitud en los estudios sobre la sociedad asturleonesa medieval es un buen ejemplo de hasta qué punto los historiadores somos prisioneros de tramas discursivas tejidas por añejas inercias académicas. La obsesión de buena parte del medievalismo hispano de los años 70-90 por disputas que hoy nos parecen absurdas, como el cuestionamiento de la romanización del norte peninsular o la banalización de la noción de feudalismo como categoría social, condenaron al ostracismo un fenómeno bien arraigado en una amplia zona del noroeste peninsular (como mucho, se reconocía en el esclavismo un "rasgo local" propio de Galicia), mientras al mismo tiempo particularismos castellanos como las behetrías eran elevados a la condición de arquetipos de validez general ${ }^{106}$.

\footnotetext{
${ }^{105}$ Lo señalaba ya Élida García García, San Juan Bautista de Corias..., p. 225. El estudio de referencia sobre el tema es, evidentemente, Juan Ignacio Ruiz de la PeÑa Solar, Las "polas» asturianas en la Edad Media. Estudio y diplomatario, ed. Universidad de Oviedo, Oviedo, 1981.

${ }^{106}$ Con casos extremos como el trabajo de referencia de Esther Pascua Echegaray et alii, "Baja Nobleza: aproximación a la historiografía europea y propuesta para una investigación”, Historia Social, 20 (1994), pp. 23-46, donde resulta evidente que para la Corona de Castilla se está razonando esencialmente a partir
} 
A fin de cuentas, si hace años Timothy Reuter decía con ironía mal contenida, en su comentario al debate sobre la "revolución feudal", que todos sabíamos en nuestros corazones que la historia medieval de Europa es esencialmente la historia de Francia, y que una explicación que se ajuste al caso francés será sin duda válida para el conjunto de Europa ${ }^{107}$, en España podemos afirmar que si algo nos dejó claro la historiografía dominante durante el último tercio del siglo pasado es que la historia de la Alta Edad Media hispana era, ante todo, la historia de la provincia de Burgos ${ }^{108}$. De modo que la escasa incidencia del esclavismo en la Castilla condal es seguramente uno de los factores que más han contribuido a su damnatio memoriae en la historiografía de las últimas décadas relativa al noroeste peninsular ${ }^{109}$.

En el presente trabajo se ha tratado de demostrar por el contrario que al menos en el país asturleonés, muy especialmente al norte de la Cordillera, la esclavitud productiva fue un factor de gran importancia dentro de la economía señorial, con una evolución muy lenta hacia formas de dependencia personal más laxa que a su vez no desaparecerían hasta los albores de la Baja Edad Media. Aunque una cierta pereza intelectual haya podido llevar a minusvalorar de antemano las referencias al fenómeno en nuestras fuentes como mero signo de arcaísmo lingüístico e ideológico, la lectura cuidadosa de la documentación muestra la existencia de relaciones de explotación de carácter esclavista que, lejos de ser un fantasma libresco, dejaron su huella en el léxico patrimonial romance de la época (criazón, mançebo) $)^{110}$, y cuya recurrente asociación con los monasterios

de los diviseros de las behetrías, mientras que por ejemplo un grupo tan significativo como los hidalgos apenas es mencionado en una ocasión, y de pasada (p. 41).

107 Timothy Reuter, "Debate. The 'Feudal Revolution'. III", Past \& Present, 155 (1997), pp. 187-8.

${ }^{108}$ Con algunas incursiones, si acaso, en las vecinas Cantabria y La Rioja, que compartían con Burgos el honor de ser cuna del castellano. En todo caso, la analogía no es inocente: el sesgo castellano en los estudios de Alta Edad Media peninsular de las últimas décadas empalidece frente al asombroso caso del debate sobre la mutación feudal en la historiografía francesa, donde un modelo propuesto desde dos de las regiones mejor documentadas de la Europa anterior al año mil (el Mâconnais de Duby y la Cataluña de Bonnassie) pudo ser refutado sin mayor escándalo a partir del estudio de una comarca como el Vendômois, que cuenta con apenas 12 documentos conservados para el siglo $\mathrm{X}$, según cómputo del propio Dominique Barthélemy, La société dans le comté de Vendôme de l'an mil au XIV́ siècle, ed. Librairie Arthème Fayard, Paris, 1993, p. 20. Y la ampliación de las fuentes utilizadas por dicho autor hacia otras áreas de la Francia central sigue sin resolver el problema, ya que la escasez de testimonios anteriores al siglo XI es algo que afecta a toda la región, según apunta Juan José LARREA, "Esclavitud y servidumbre...., p. 58. Dado que el argumento central de Duby y Bonnassie era que en el siglo XI tenía lugar una ruptura con respecto al sistema social de la centuria previa, ¿cómo valorar si ese cambio existió o no cuando se carece de información para la época anterior? Independientemente del talento de Barthélemy para atender a los matices y ofrecer lecturas reflexivas de los documentos, que es innegable, el hecho demuestra lo frágiles que son los ejes sobre los que gira el decurso historiográfico del medievalismo en general, no sólo del hispano.

109 Aunque esta convención historiográfica sobre la práctica inexistencia de esclavitud en Castilla queda en entredicho si se admite como válida la identificación entre casatos y esclavos que propone con buenos argumentos Ernesto Pastor Díaz de Garayo, Castilla en el tránsito..., pp. 283-285.

110 Vid. supra apartado 1.2. La mera atención desprevenida a la evolución terminológica de servus y famulus como aparente indicador social fiable, sin tener en cuenta la problemática relación -en modo alguno automática- entre la evolución respectiva del léxico y la sociedad, ignorando por ejemplo que ninguno de 
familiares (vid. Anexo) es un indicio claro del papel que desempeñaban en el corazón de las explotaciones magnaticias. Por supuesto, la mera acumulación cuantitativa de referencias no es suficiente: su estudio requiere someter las fuentes disponibles a un detenido análisis de carácter cualitativo (su procedencia, génesis documental, intencionalidad, cronología, vocabulario...), atendiendo a los diversos caveat que se han venido señalando en las páginas anteriores.

En todo caso, este artículo no pretende ser más que una invitación a seguir investigando sobre una temática fascinante. Ya se ha señalado la necesidad de dedicar un estudio específico a la desaparición de las formas de dependencia personal, pero muchas otras cuestiones siguen abiertas. Por ejemplo, sería muy interesante replantear la esclavitud doméstica desde una perspectiva que no la trate de "improductiva" y casi irrelevante: gracias en particular a las aportaciones de la antropología y el feminismo, la investigación de las últimas décadas en ciencias sociales ha hecho importantes avances en el análisis de la economía, asumiendo -se trata en realidad de una vieja propuesta marxista- la importancia de las tareas asociadas no sólo a la producción sino también a la reproducción de la sociedad, dentro de las cuales juega un gran papel la esfera doméstica. Es apenas una muestra de que queda, sin duda, mucho trabajo por hacer ${ }^{111}$.

ambos términos es el más significativo para designar a los esclavos en la documentación altomedieval, es precisamente lo que lastra las conclusiones generales del trabajo de $\mathrm{M}^{\mathrm{a}}$ Isabel LoRING GARCía y Pablo Fuentes Hinojo, "Esclavitud y servidumbre en el tránsito del mundo antiguo al medieval", Romanización y Reconquista en la Península Ibérica: Nuevas perspectivas, $\mathrm{M}^{\mathrm{a}}$ José Hidalgo, Dionisio Pérez y Manuel J. R. Gervás (eds.), ed. Universidad de Salamanca, 1998, pp. 247-256.

${ }^{111} \mathrm{He}$ dejado fuera del presente trabajo el análisis de la esclavitud en la ciudad y su entorno, tema que trato en el apartado III.5 de mi tesis doctoral: Raúl GonzÁlez GonZÁlez, Élites urbanas y relaciones de poder en Oviedo, León y Astorga durante la Edad Media (siglos IX-XIII), Universidad de Oviedo, 2017, pp. 288-313. 


\section{ANEXO ${ }^{112}$ \\ TABLA I \\ Referencias documentales a la esclavitud en el Bierzo y la cuenca leonesa del Duero (800-1050) ${ }^{113}$}

\begin{tabular}{|c|c|c|c|}
\hline Año & Negocio & Localización de los dependientes & Referencia \\
\hline $\begin{array}{l}854 \\
\text { (refacc. del s. } \\
\text { XI) }\end{array}$ & $\begin{array}{l}\text { Ordoño I confirma a Purello } \\
\text { la propiedad de la villa de } \\
\text { Valdoré, que había tomado } \\
\text { en presura }\end{array}$ & $\begin{array}{c}\text { Castro Donna, probablemente } \\
\text { situado sobre el río Dueñas, en la } \\
\text { Montaña leonesa }{ }^{114}\end{array}$ & Otero $\mathrm{n}^{\circ} 1$ \\
\hline $\begin{array}{l}873 \text { (perdido, } \\
\text { editado por } \\
\text { Risco en el s. } \\
\text { XVIII) } \\
\end{array}$ & $\begin{array}{c}\text { Donación del obispo } \\
\text { Frunimio a la iglesia de } \\
\text { Santiago y Sta. Eulalia de } \\
\text { Viñayo } \\
\end{array}$ & $\begin{array}{l}\text { Viñayo (Carrocera, León), en la } \\
\text { Montaña central leonesa }\end{array}$ & $\mathrm{CCL} \mathrm{n}^{\circ} 5$ \\
\hline 917 (original) & $\begin{array}{c}\text { Donación del obispo } \\
\text { Frunimio a S. Cristóbal de } \\
\text { León } \\
\end{array}$ & $\begin{array}{c}\text { Villas de Cornelius, Marco y } \\
\text { Eddane, en el Páramo, más allá del } \\
\text { Esla (León) }\end{array}$ & CCL n ${ }^{\circ} 43$ \\
\hline $\begin{array}{l}930 \text { (copia del } \\
\text { s. XIII) }\end{array}$ & $\begin{array}{l}\text { Donación del conde Cid al } \\
\text { monasterio de S. Pedro de } \\
\text { Montes }\end{array}$ & Borrenes (El Bierzo) & $\mathrm{TVM} \mathrm{n}^{\circ} 12$ \\
\hline
\end{tabular}

${ }_{112}$ Como justificación de la importancia de la esclavitud en el ámbito de estudio del presente trabajo, y en atención a diversos comentarios de los evaluadores del artículo, se incluye como anexo una relación pormenorizada de las alusiones documentales a esclavos al norte y al sur de la Cordillera. Por motivos de estricta economía espacial la muestra se reduce al período que va hasta mediados del s. XI (para una relación completa hasta el año 1100, vid. Raúl GonzÁlez GonZÁlEz: Élites urbanas y relaciones de poder..., pp. 804-858). No incluyo en el cómputo las falsificaciones tardías (como las donaciones de reyes asturleoneses recogidas en el Liber Testamentorum, y donde los originales, si es que existieron, son irreconocibles), pero sí los documentos rehechos o interpolados que pueden ser aprovechados, atendiendo sólo a las partes que parecen remitir al original (como la enumeración de criazones en la donación de Sto. Adriano de Tuñón del 891), no las interpolaciones tardías evidentes como la regulación de las obligaciones laborales de las criazones en el supuesto documento fundacional de Obona o la cláusula sobre la facultad de los servi del rey para donar 1/5 de sus bienes a la Iglesia que aparece en numerosos documentos pelagianos. Tampoco se incluyen las alusiones genéricas a homines dependientes en las que no se especifica la naturaleza de su sujeción (salvo algunos pocos casos debidamente justificados), ni los testimonios que utilizan términos como servus o puer con un significado ajeno al de esclavo. ${ }_{113}$ Por "cuenca leonesa del Duero" podemos entender el espacio delimitado por la Cordillera Cantábrica al norte, el Bierzo y Sanabria al oeste, el Duero al sur y el condado de Monzón al este, de modo que abarcaría territorios pertenecientes a las actuales provincias de León, Zamora, Valladolid y Palencia y se correspondería aproximadamente con lo que las fuentes posteriores denominan "tierra de León" (Juan José SÁNCHEZ BAdioLA, El territorio de León..., vol. II, pp. 706-7). Así Alfonso VI, al promulgar las normas para la resolución de conflictos entre cristianos y judíos en la terra de Legione, señala como principales autoridades eclesiásticas de la misma al abad de Sahagún y los obispos de León y Astorga: Sah no 858 (1090), CCL nº 1256 (1091); y Lucas de Tuy la delimita en estos términos: "Terra Leonis dicitur per flumen de Pisorga et per flumen Dorii et per montes Submontanorum" (Lucas Tudensis, Chronicon Mundi, IV, 75; ed. Falque Rey, Brepols, Turnhout, 2003, p. 317), que en un pasaje posterior diferencia expresamente del Bierzo (ibid., IV, 86; ed. pp. 326-7).

114 Según indican Carlos Manuel Reglero de la Fuente, "La ocupación de la Cuenca del Duero leonesa por el reino astur", La época de Alfonso III y San Salvador de Valdediós, Oviedo, Universidad de Oviedo, 1994, p. 130 y Juan José Sánchez Badiola, El territorio de León..., vol. I, p. 134. 


\begin{tabular}{|c|c|c|c|}
\hline Año & Negocio & Localización de los dependientes & Referencia \\
\hline $\begin{array}{c}936 \text { (copia } \\
\text { del s. XII } \\
\text { en el Tumbo } \\
\text { Legionense) }\end{array}$ & $\begin{array}{l}\text { Testamento del diácono } \\
\text { Hermenegildo Felici }\end{array}$ & $\begin{array}{c}\text { Sin determinar. El documento alude a } \\
\text { bienes en Asturias y León, sin mayor } \\
\text { especificación. }\end{array}$ & $\mathrm{CCL} \mathrm{n}^{\circ} 109$ \\
\hline 949 (original) & $\begin{array}{c}\text { Dotación del monasterio de } \\
\text { Santiago de Valdavida por } \\
\text { Vermudo Núñez } \\
\end{array}$ & $\begin{array}{l}\text { Valdavida (Villaselán, León), en la } \\
\text { comarca de Tierra de Cea }\end{array}$ & $\begin{array}{l}\text { Sahagún } \mathrm{n}^{\circ} \\
114\end{array}$ \\
\hline 950 (original) & $\begin{array}{l}\text { Dotación del monasterio } \\
\text { de S. Juan de Vega de } \\
\text { Monasterio por el obispo } \\
\text { Oveco de León }\end{array}$ & $\begin{array}{c}\text { Vega de Monasterio (Cubillas de } \\
\text { Rueda, León), en la comarca de } \\
\text { Tierra de Rueda }\end{array}$ & $\mathrm{CCL} \mathrm{n}^{\circ} 220$ \\
\hline 962 (original) & $\begin{array}{l}\text { Carta de arras de Gonzalo en } \\
\text { favor de su esposa Elvira }\end{array}$ & $\begin{array}{c}\text { Sin especificar. La donación se } \\
\text { refiere a bienes en Castilla, Liébana } \\
\text { y el espacio oriental de la tierra de } \\
\text { León. }\end{array}$ & $\begin{array}{l}\text { Sahagún } \mathrm{n}^{\circ} \\
\quad 207\end{array}$ \\
\hline 963 (original) & $\begin{array}{l}\text { Diego Ovéquiz vende una } \\
\text { heredad a Fruela Vigílaz }\end{array}$ & $\begin{array}{l}\text { Villa de Goma ad Sancti Martini, } \\
\text { cerca de Carrión de los Condes } \\
(\text { Palencia })^{115} \text {, en Tierra de Campos }\end{array}$ & $\begin{array}{l}\text { Sahagún } \mathrm{n}^{\circ} \\
211\end{array}$ \\
\hline $\begin{array}{l}970 \text { (copia del } \\
\text { s. XVII) }\end{array}$ & $\begin{array}{c}\text { Donación del abad } \\
\text { Armentario al monasterio de } \\
\text { S. Acisclo } \\
\end{array}$ & Castropodame (E1 Bierzo) & $\mathrm{CCA} \mathrm{n}^{\circ} 20$ \\
\hline $\begin{array}{l}988 \text { (copia del } \\
\text { s. XIII) }\end{array}$ & $\begin{array}{l}\text { Vermudo II dona diversos } \\
\text { hombres al monasterio de S. } \\
\text { Julián de Samos }\end{array}$ & $\begin{array}{c}\text { Villasinde, Balboa y Villadepalos }{ }^{116} \\
\text { (en El Bierzo, respectivamente en } \\
\text { los municipios de Vega de Valcarce, } \\
\text { Balboa y Carracedelo) }\end{array}$ & $\operatorname{Samos~}^{\circ} 56$ \\
\hline $\begin{array}{c}992 \text { (copias de } \\
\text { los siglos XVII } \\
\text { y XVIII) }\end{array}$ & $\begin{array}{l}\text { Vermudo II dona diversos } \\
\text { hombres al monasterio de } \\
\text { Sta. Leocadia de Castañeda }\end{array}$ & \begin{tabular}{|} 
Diversas localidades en El Bierzo, \\
en los municipios de Palacios del Sil, \\
Páramo del Sil, Noceda del Bierzo, \\
Bembibre, Toreno, Cubillos del Sil \\
y Berlanga del Bierzo. Además, sin \\
localizar o dudosos: Villa Ellanes ${ }^{117}$, \\
Sancto Salvatore (¿S. Salvador de \\
Bárcena? ${ }^{118}$ ), Castro, Penellas y \\
Sancta Maria de Mallo
\end{tabular} & $\operatorname{CCA~n}^{\circ} 171$ \\
\hline
\end{tabular}

115 La sitúa cerca de Carrión Pascual Riesco Chueca, "Breves calas en la antroponimia germánica leonesa", Argutorio, 30 (2013), p. 118.

116 Tomo la identificación de Sancto Iohane con el antiguo S. Juan de Viogio, actual Villadepalos, del índice toponímico de Samos, p. 603.

117 Probablemente deba identificarse con el lugar de Elán, que un documento posterior sitúa en la zona de Magaz (Arganza - Camponaraya): CCA n ${ }^{\circ} 623$ (1125).

118 Monasterio que estaba emplazado en la localidad de Bárcena del Sil, hoy anegada por el embalse homónimo: Iñaki MarTín VIso, "Monasterios y redes sociales en el Bierzo altomedieval”, Hispania, 237 (2011), p. 17.

119 Quizá próximo al actual San Pedro Mallo (Toreno). 


\begin{tabular}{|c|c|c|c|}
\hline Año & Negocio & Localización de los dependientes & Referencia \\
\hline $\begin{array}{l}994 \text { (copia } \\
\text { del s. XII } \\
\text { en el Tumbo } \\
\text { Legionense) }\end{array}$ & $\begin{array}{l}\text { Cida Aion entrega al conde } \\
\text { Munio Fernández una } \\
\text { heredad para evitar ser } \\
\text { esclavizada como condena } \\
\text { por adulterio }\end{array}$ & Valdevimbre (León), en el Páramo & $\mathrm{CCL} \mathrm{n}^{\circ} 561$ \\
\hline $\begin{array}{l}996 \text { (copia de } \\
\text { la } 2^{\text {a }} \text { mitad del } \\
\text { s. XI) }\end{array}$ & $\begin{array}{c}\text { Vermudo II dona varios } \\
\text { hombres a la comunidad } \\
\text { eremítica de Pardomino, } \\
\text { con la condición de que } \\
\text { sirvan como libres, no como } \\
\text { esclavos }\end{array}$ & $\begin{array}{l}\text { Pardomino (Boñar, León), en la } \\
\text { Montaña oriental leonesa }\end{array}$ & CCL n ${ }^{\circ} 574$ \\
\hline $\begin{array}{l}\text { 984-999 (sólo } \\
\text { se conserva un } \\
\text { regesto del s. } \\
\text { XVIII) }\end{array}$ & $\begin{array}{c}\text { Donación de Justa, alias Sol, } \\
\text { al monasterio de SS. Acisclo } \\
\text { y Román }\end{array}$ & $\begin{array}{l}\text { Requejo de la Vega (Soto de la Vega, } \\
\text { León), en la comarca de La Bañeza }\end{array}$ & $\mathrm{CCA} \mathrm{n}^{\circ} 151$ \\
\hline $\begin{array}{l}\text { c. } 985-1007^{120} \\
\text { (noticia } \\
\text { recogida en un } \\
\text { doc. de } 1026 \\
\text { copiado en } \\
\text { el s. XII en } \\
\text { el Tumbo } \\
\text { Legionense) }\end{array}$ & $\begin{array}{c}\text { El conde Diego Fernández } \\
\text { de Saldaña tomó y despobló } \\
\text { Villa Revelle, llevándose a } \\
\text { sus habitantes para instalarlos } \\
\text { en una populatione de su } \\
\text { propiedad }^{121}\end{array}$ & $\begin{array}{l}\text { Villa Revelle, en Valderratario } \\
\text { (Calzada del Coto, León), en la } \\
\text { comarca de Tierra de Sahagún }\end{array}$ & CCL n ${ }^{\circ} 829$ \\
\hline $\begin{array}{l}1018 \text { (copia } \\
\text { del s. XII } \\
\text { en el Tumbo } \\
\text { Legionense) }\end{array}$ & $\begin{array}{c}\text { Donación del presbítero } \\
\text { Sampiro al monasterio de } \\
\text { Santiago de León de las } \\
\text { villas de Villaturiel y Alija } \\
\text { de la Ribera. Esta segunda la } \\
\text { había recuperado de la reina } \\
\text { Elvira mediante la oferción } \\
\text { de dos moros }\end{array}$ & $\begin{array}{l}\text { Sin determinar, pero muy } \\
\text { probablemente León }\end{array}$ & $\mathrm{CCL} \mathrm{n}{ }^{\circ} 756$ \\
\hline
\end{tabular}

${ }^{120}$ El documento de 1026 fecha el secuestro y traslado de los hombres de Villa Revelle en el tiempo de la alfetena (al-fitna o guerra civil), con anterioridad al episcopado de Nuño. Pascual Martínez Sopena, "Reyes, condes e infanzones. Aristocracia y alfetena en el reino de León", Ante el milenario del reinado de Sancho el Mayor: un rey navarro para España y para Europa (Estella, 14 a 18 de julio de 2003), ed. Gobierno de Navarra, Pamplona, 2004, p. 133, supone una datación de c. 1007 para tales hechos, pero el texto parece presentarlos como algo que ocurre ya algún tiempo antes de la llegada de Nuño al episcopado. En todo caso, el incidente debió de ocurrir en el transcurso de alguno de los graves conflictos internos que sacudieron el reino de León durante el reinado de Vermudo II y la minoría de edad de Alfonso V, por lo que doy las fechas extremas del acceso al trono de aquél y el inicio del episcopado de Nuño en 1007.

${ }^{121}$ El caso es interesante porque supone una esclavización en la práctica, con independencia de cuál fuese la condición personal originaria de los habitantes de Villa Revelle. 


\begin{tabular}{|c|c|c|c|}
\hline Año & Negocio & Localización de los dependientes & Referencia \\
\hline 1019 (original) & $\begin{array}{l}\text { Alfonso V dona a su fiel } \\
\text { Pedro Flaínez dos villas } \\
\text { confiscadas a rebeldes }\end{array}$ & $\begin{array}{c}\text { Disposición legal de carácter } \\
\text { genérico. Las villas referidas estaban } \\
\text { situadas en La Acisa y Sobrepeña, } \\
\text { localidades del actual concejo de } \\
\text { La Ercina, en la Montaña oriental } \\
\text { leonesa. } \\
\end{array}$ & $\begin{array}{l}\text { Otero } \mathrm{n}^{\circ} \\
124\end{array}$ \\
\hline $\begin{array}{l}1021 \text { (sólo se } \\
\text { conserva un } \\
\text { regesto del s. } \\
\text { XVIII) }\end{array}$ & $\begin{array}{l}\text { Inventario de bienes de la } \\
\text { iglesia de Astorga }\end{array}$ & $\begin{array}{l}\text { Diversos lugares en El Bierzo: } \\
\text { Dragonte, San Feliz, Corullón, } \\
\text { Vilela, Orta, Otero, Toral, } \\
\text { Villadecanes, Castro de la Ventosa, } \\
\text { Pieros (Penarios), San Martín, } \\
\text { Sorribas y Robledo. }\end{array}$ & $\mathrm{CCA} \mathrm{n}^{\circ} 232$ \\
\hline 1022 (original) & $\begin{array}{c}\text { Pleito contra Emlo por } \\
\text { haber inducido al robo a una } \\
\text { esclava del conde }{ }^{123} \text { Fruela } \\
\text { Muñoz }\end{array}$ & $\begin{array}{l}\text { Viñayo (Carrocera, León) })^{124} \text {, en la } \\
\text { Montaña central leonesa }\end{array}$ & $\begin{array}{l}\text { Otero } n^{\circ} \\
147\end{array}$ \\
\hline 1022 (original) & $\begin{array}{c}\text { Debido a un intento de } \\
\text { rapto, Íñigo y Midueña se } \\
\text { comprometen a servir de por } \\
\text { vida al conde Fruela Muñoz } \\
\text { y su mujer Amuna }{ }^{125} \\
\end{array}$ & $\begin{array}{c}\text { No hay especificación de lugar, pero } \\
\text { debe situarse probablemente en la } \\
\text { comarca de la Montaña leonesa, } \\
\text { centro de la actividad del conde } \\
\text { Fruela Muñoz. } \\
\end{array}$ & $\begin{array}{l}\text { Otero } n^{\circ} \\
151\end{array}$ \\
\hline 1034 (original) & $\begin{array}{c}\text { Carta de arras de Asur } \\
\text { Gómez en favor de su esposa } \\
\text { Mumadoña }\end{array}$ & $\begin{array}{l}\text { Sin determinar. La donación incluye } \\
\text { dos villas cercanas a Sahagún, en } \\
\text { Tierra de Campos: S. Martín (S. } \\
\text { Martín de la Fuente, pedanía del } \\
\text { municipio de Moratinos, Palencia) y } \\
\text { Villela (despobl. próx. a Santervás de } \\
\text { Campos, Valladolid }{ }^{126} \text { ) }\end{array}$ & $\begin{array}{l}\text { Sahagún } n^{\circ} \\
439\end{array}$ \\
\hline
\end{tabular}

${ }^{122}$ El regesto ofrece el término "vasallos", anacrónico y terriblemente impreciso, pero cabe pensar que el redactor del Tumbo Negro que recoge la noticia tuviese ante sus ojos una de esas pesquisas sobre heredades y hombres de criazón que encontramos en otras fuentes de la época. Sin embargo, el paralelo sí conservado de CCA n ${ }^{\circ} 253$ (1027), donde la referencia a homines parece indicar meramente jurisdicción sobre hombres libres (no se da por ejemplo una nómina personal de los dependientes), mueve a la duda. Otros inventarios posteriores sí recogen el nombre de los dependientes, aunque por lo general su contexto parece remitir más bien a siervos personales que a esclavos: CCA no 434 (1084), CCA no 466 (1093) y CCA no 482 (s. XI).

123 Aunque el documento no hace mención expresa de su condición de conde, el personaje es bien conocido, al menos desde el artículo de Alfonso Prieto Prieto, "El conde Fruela Muñoz. Un asturiano del siglo XI", Asturiensia Medievalia, 2 (1975), pp. 11-37.

${ }_{124}$ El documento no especifica la localización, pero Otero $n^{\circ} 148$ (1022) recoge la entrega de varias tierras en Viñayo a Fruela Muñoz por parte de Emlo en compensación por el hurto.

125 Vid. supra nota 123. Íñigo, con ayuda de su madre y su hermano, había raptado a Midueña, que era cubileira de Fernando Muñoz (Otero $\mathrm{n}^{\circ}$ 150, año 1022).

126 Sebastián de Miñano y Bedoya, Diccionario geográfico-estadístico de España y Portugal, vol. X, ed. Imprenta de Pierart-Peralta, Madrid, 1828, p. 12, s.v. "Villela (en prov. y obisp. de León)". 


\begin{tabular}{|c|c|c|c|}
\hline Año & Negocio & Localización de los dependientes & Referencia \\
\hline $\begin{array}{l}1038 \text { (copia } \\
\text { del s. XII } \\
\text { en el Tumbo } \\
\text { Legionense) }\end{array}$ & $\begin{array}{c}\text { Dotación del monasterio de } \\
\text { S. Antolín del Esla por los } \\
\text { condes Rodrigo Galíndez y } \\
\text { Sancha }\end{array}$ & $\begin{array}{c}\text { Granja de San Antolín (Cabreros } \\
\text { del Río, León), en la comarca Esla- } \\
\text { Campos }\end{array}$ & $\begin{array}{l}\text { CCL n }{ }^{\circ} 970 \\
\quad \text { y } 971\end{array}$ \\
\hline $\begin{array}{l}1043 \text { (copia } \\
\text { del s. XIV) }\end{array}$ & $\begin{array}{c}\text { Privilegio de exención } \\
\text { concedido por Fernando I a } \\
\text { los hombres del monasterio } \\
\text { de S. Andrés de Espinareda }\end{array}$ & Vega de Espinareda (El Bierzo) & $\begin{array}{l}\text { Espinareda } \\
\mathrm{n}^{\circ} 1\end{array}$ \\
\hline $\begin{array}{l}1045 \text { (copia } \\
\text { coetánea) }\end{array}$ & $\begin{array}{l}\text { Carta de arras del conde }{ }^{127} \\
\text { Fruela Muñoz en favor de su } \\
\text { esposa Gontrodo }\end{array}$ & $\begin{array}{l}\text { Sin determinar. El documento alude } \\
\text { a bienes en diversos lugares de } \\
\text { Asturias y León, principalmente en } \\
\text { zonas de la Cordillera. }\end{array}$ & $\begin{array}{l}\text { Otero } n^{\circ} \\
237\end{array}$ \\
\hline 1047 (original) & $\begin{array}{l}\text { Donación de Florentina al } \\
\text { monasterio de Sahagún }\end{array}$ & $\begin{array}{c}\text { Santa Cristina de Valmadrigal } \\
\text { (León), en la comarca Esla-Campos }\end{array}$ & $\begin{array}{l}\text { Sahagún } \mathrm{n}^{\circ} \\
504\end{array}$ \\
\hline $\begin{array}{c}1^{\mathrm{a}} \text { mitad del } \\
\text { s. XI (noticia } \\
\text { de c. } 1073- \\
1090 \text { recogida } \\
\text { después en el } \\
\text { Liber) }\end{array}$ & $\begin{array}{c}\text { Nómina de los hombres de } \\
\text { Cartavio que el abad Munio } \\
\text { tiene en préstamo del obispo } \\
\text { de Oviedo }\end{array}$ & $\begin{array}{c}\text { El esclavo Trasmiro era originario } \\
\text { del Bierzo }\end{array}$ & LTO n 46 \\
\hline
\end{tabular}

TABLA II

\section{Referencias documentales a la esclavitud en Asturias (800-1050)}

\begin{tabular}{|c|c|c|c|}
\hline Año & Negocio & $\begin{array}{c}\text { Localización de los } \\
\text { dependientes }\end{array}$ & Referencia \\
\hline $\begin{array}{c}812 \text { (refacción } \\
\text { de comienzos } \\
\text { del s. X) }\end{array}$ & $\begin{array}{c}\text { Donación de Alfonso II a la iglesia } \\
\text { de Oviedo }\end{array}$ & Oviedo (ciudad) & CCO n $^{\circ} 2$ \\
\hline
\end{tabular}

127 Vid. supra nota 123.

128 Las fechas extremas para la redacción de la noticia vienen dadas por la mención al obispo Arias (10731094) y por la relación del documento con LTO no 45 (1090). Pero Trasmiro, el esclavo procedente del Bierzo, es mencionado como anterior en dos generaciones a la época en que se elabora la nómina.

129 Parece haber sido copiado entonces para un primitivo proyecto de cartulario de la catedral de Oviedo, que no prosperó: Ma Josefa SAnz Fuentes, "Estudio paleográfico", Liber Testamentorum Ecclesiae Ovetensis, ed. M. Moleiro Editor, Barcelona, 1995, p. 135; Elena E. RodRíguez DíAz, "Notas codicológicas sobre el llamado Testamento del Rey Casto", Asturiensia Medievalia, 8 (1995-1996), pp. 71-78; Ma Josefa Sanz Fuentes y Miguel Calleja Puerta, Litteris confirmentur. Lo escrito en Asturias en la Edad Media, ed. Cajastur, Oviedo, 2005, pp. 59 y 63. Su contenido no obstante no parece haber sido alterado de forma significativa, si tenemos en cuenta lo limitado de la donación (la propia iglesia, ajuar litúrgico, libros y esclavos, sin referencia a otro tipo de bienes o derechos), que el documento mantiene una perspectiva ajena al neogoticismo imperante en la corte asturleonesa desde época de Alfonso III o que ofrece todavía la lista nominal de esclavos cedidos, a diferencia de lo que ocurre con la versión recogida en el Liber Testamentorum, donde aparece reducida a una mera fórmula (LTO $\mathrm{n}^{\circ} 8$ ). 


\begin{tabular}{|c|c|c|c|}
\hline Año & Negocio & $\begin{array}{l}\text { Localización de los } \\
\text { dependientes }\end{array}$ & Referencia \\
\hline $\begin{array}{l}863 \text { (refacción } \\
\text { del s. XIII) }{ }^{130}\end{array}$ & $\begin{array}{l}\text { Donación del obispo Gladila a la } \\
\text { iglesia de Sta. María de Trubia }\end{array}$ & $\begin{array}{c}\text { Diversos lugares en los } \\
\text { concejos de Proaza y Oviedo }\end{array}$ & $\mathrm{CCO}$ n $^{\circ} 8$ \\
\hline $\begin{array}{l}891 \text { (copia } \\
\text { del s. XIV de } \\
\text { una versión } \\
\text { interpolada } \\
\text { anterior) }^{131}\end{array}$ & $\begin{array}{l}\text { Dotación fundacional del } \\
\text { monasterio de Santo Adriano de } \\
\text { Tuñón por Alfonso III }\end{array}$ & $\begin{array}{c}\text { Sin especificar, pero } \\
\text { probablemente en el } \\
\text { propio emplazamiento } \\
\text { del monasterio en Tuñón } \\
\text { (Proaza) }\end{array}$ & $\begin{array}{l}\text { ReglaCol } \\
\quad n^{0} 2\end{array}$ \\
\hline c. 893 & $\begin{array}{c}\text { Imprecación contra los que } \\
\text { intenten llevarse bienes del templo } \\
\text { de S. Salvador, fundado en } 893 \\
\text { por Alfonso III }\end{array}$ & $\begin{array}{c}\text { Iglesia de S. Salvador } \\
\text { de Boides (Valdediós, } \\
\text { Villaviciosa) }\end{array}$ & $\begin{array}{l}\text { Inscripciones } \\
\quad \mathrm{n}^{\circ} 228\end{array}$ \\
\hline $\begin{array}{l}921 \text { (refacción } \\
\text { pelagiana) }\end{array}$ & $\begin{array}{c}\text { Donación de Ordoño II a la iglesia } \\
\text { de Oviedo }{ }^{132}\end{array}$ & $\begin{array}{l}\text { Villas de Naón y Granda, e } \\
\text { iglesias de S. Martín, Sto. } \\
\text { Tomás, S. Pelayo y Sta. } \\
\text { Eugenia (todo en Siero) }\end{array}$ & LTO n ${ }^{\circ} 18$ \\
\hline
\end{tabular}

${ }^{130}$ La escritura se basa sin duda en un núcleo documental auténtico, y cabe admitir lo fundamental de su contenido (la fundación a mediados del siglo IX por Gladila, un magnate que acabaría por ocupar la mitra episcopal de Lugo-Braga, de un centro monástico en Trubia al que dotó con diversas propiedades en la zona, donde había manumitido a varios de sus esclavos), aunque las evidentes manipulaciones presentes en la copia que ha llegado hasta nosotros parecen remitir a una refundición de varios originales. Vid. un detenido estudio del documento en Francisco Javier Fernández Conde y Jesús Fernández Fernández, "Abades, obispos y poder social", Territorio, Sociedad y Poder, 4 (2009), pp. 65-94.

131 Aunque se trata de un testimonio muy rehecho, algunas partes parecen provenir del original perdido. Tal es precisamente el caso de la nómina de dependientes, que aparece descontextualizada en la versión del documento que ha llegado hasta nosotros, sin duda como resultado de las interpolaciones introducidas en el texto: Francisco Javier Fernández Conde y Ma Antonia Pedregal Montes, "Santo Adriano de Tuñón. Historia de un territorio en los siglos de transición", Asturiensia Medievalia, 8 (1995-1996), pp. 97 y 107. Elena E. Rodríguez Díaz señala en ReglaCol p. 141 que la versión de la Regla Colorada está tomada del Libro de los Privilegios, que a su vez debió de recoger el texto de una refacción en letra carolina del original en escritura visigótica. Dado que las copias incorporadas a los códices elaborados por orden del obispo Don Gutierre en el siglo XIV son muy fieles a sus modelos, las interpolaciones deben atribuirse a dicha refacción carolina, que podría fecharse en algún momento del siglo XII posterior al episcopado de Pelayo, quien no lo incluyó en el Liber Testamentorum ni lo utilizó como modelo para redactar la donación de Santo Adriano de Tuñón a la catedral por Alfonso VI (LTO n 47). Andrés Gambra tacha a esta última de falsa (Gambra $\mathrm{n}^{\mathrm{o}} 35$ ), atendiendo a su vinculación con el problemático documento de Alfonso III, pero Francisco Javier Fernández Conde y Ma Antonia Pedregal Montes, "Santo Adriano de Tuñón...", pp. 95-6, señalan que el texto pelagiano no depende de él (de hecho no incluye los aspectos más problemáticos del documento de 891, como la donación de propiedades leonesas o la concesión del coto). Tendría más sentido que la donación de Alfonso VI fuese auténtica, y que algún tiempo después, ya consolidada la incorporación de Santo Adriano al dominio catedralicio, se interpolase un diploma de Alfonso III aprovechando elementos del texto pelagiano e incorporando concesiones aún mayores.

${ }^{132}$ Lo limitado de esta donación (2 villas y varias iglesias en una zona muy concreta) la diferencia de las habituales entregas de bienes innumerables que recoge el Liber para otros reyes asturleoneses, por lo que -por muy rehecho que esté en su redacción- parece probable que el documento remita a un original (seguramente más de donación de villas que de iglesias). 


\begin{tabular}{|c|c|c|c|}
\hline Año & Negocio & $\begin{array}{c}\text { Localización de los } \\
\text { dependientes }\end{array}$ & Referencia \\
\hline $\begin{array}{c}\text { 936 (copia del s. } \\
\text { XII en el Tumbo } \\
\text { Legionense) }\end{array}$ & $\begin{array}{c}\text { Testamento del diácono } \\
\text { Hermenegildo Felici }\end{array}$ & $\begin{array}{c}\text { Sin determinar. El } \\
\text { documento alude a bienes en } \\
\text { Asturias y León, sin mayor } \\
\text { especificación. }\end{array}$ & CCL n 109 \\
\hline $\begin{array}{c}\text { Mediados del s. } \\
\mathrm{X}^{133} \text { (noticia del } \\
\text { s. XIII) }\end{array}$ & $\begin{array}{c}\text { Donación del conde Vermudo } \\
\text { Velaz al monasterio de Bárcena }\end{array}$ & Villarpadriz (Tineo) & $\begin{array}{c}\text { RC p. 168 } \\
\text { (fol. 76rA15- } \\
20)\end{array}$ \\
\hline $\begin{array}{c}967 \text { (refacción } \\
\text { pelagiana) }\end{array}$ & $\begin{array}{c}\text { Donación del obispo Diego a la } \\
\text { iglesia de Oviedo }\end{array}$ & $\begin{array}{c}\text { Iglesia de S. Felix de Hevia } \\
\text { (Siero), villas de Hevia } \\
\text { (Siero) y S. Pelayo (Grado) }\end{array}$ & LTO n 21 \\
\hline
\end{tabular}

${ }^{133}$ Francisco Javier Fernández Conde, "El monasterio de San Miguel de Bárzana (Asturias). Historia y formación del patrimonio", La Peninsula en la Edad Media treinta años después. Estudios dedicados a JoséLuis Martín, ed. Universidad de Salamanca, Salamanca, 2006, p. 122, sitúa la fundación del monasterio de Bárcena por el conde Vermudo Velaz en el primer cuarto del siglo X, en contraposición a Miguel Calleja Puerta, El conde Suero Vermúdez..., pp. 112, 173, 430 y 521-2, que identifica al fundador de Bárcena con el personaje homónimo documentado en los últimos años del s. X y comienzos del XI. Si tenemos en cuenta que una hermana de los fundadores de Bárcena (los condes Fruela y Vermudo Velaz), Jimena Velaz, era madre de doña Aragonti, fallecida en el año 1003 a una edad no demasiado avanzada, pues dejaba a su vez un hijo -el conde Piniolo Jiménez- que no moriría hasta 1049, parece sumamente improbable que esta generación de hermanos (Fruela, Vermudo y Jimena Velaz) pueda retrotraerse a comienzos del siglo X; de lo contrario, habría que suponer que apenas 3 generaciones abarcarían más de siglo y medio: desde el nacimiento de los hermanos fundadores de Bárcena, que si fundan el cenobio en el primer cuarto del s. X habría que suponer nacidos hacia fines del s. IX, hasta que Piniolo Jiménez, nieto de la fundadora Jimena (fundatrix la llama RC p. 174), muere en 1049 (Élida García García, San Juan Bautista de Corias..., p. 88. nota 34). Aunque tampoco parece probable su identificación con el Vermudo Velaz que propone Calleja Puerta, pues éste no se casaría hasta comienzos del s. XI (Miguel Calleja Puerta, El conde Suero Vermúdez..., p. 173), una cronología demasiado tardía para el fundador homónimo de Bárcena, que a la altura del año 1003 tiene ya incluso varios sobrinos-nietos (los hijos de su sobrina Aragonti, fallecida ese año), y quien ya en vida de su hermana Jimena (la madre de Aragonti) tiene otro sobrino, Oveco Sánchez, junto con quienes hace una división de esclavos en RC, pp. 168-9. En realidad, el único argumento de Fernández Conde para fechar la fundación de Bárcena en el primer cuarto del s. X es la noticia a una donación recibida por el monasterio ya en 937 (RC, pp. 178-9), por lo que nada vincula a Vermudo Velaz o sus hermanos con esa cronología. Lo más probable es que esa primera fundación haya que atribuirla a los padres de éstos, los condes Vela y Todilde, que según la "Genealogia de Varzena" de RC, pp. 181-2 "hedificaverunt de novo monasterium Sancti Micaelis de Varzena". Vermudo Velaz y sus hermanos, calificados también de fundadores en diversos pasajes del Registro coriense, serían los autores de una reedificación, como señala Francisco Javier FernÁNDEZ Conde, "El monasterio de San Miguel...", p. 120. Esto permitiría, sin alterar la fecha originaria de fundación de Bárcena en el $1^{\text {er }}$ cuarto del s. X, situar a Vermudo Velaz y sus hermanos a mediados del s. X, lo cual encaja mucho mejor con la cronología de los descendientes de Jimena. 


\begin{tabular}{|c|c|c|c|}
\hline Año & Negocio & $\begin{array}{c}\text { Localización de los } \\
\text { dependientes }\end{array}$ & Referencia \\
\hline $\begin{array}{l}972 \text { (refacción } \\
\text { pelagiana) }\end{array}$ & $\begin{array}{l}\text { Donación de Tructino Fernández } \\
\text { y su mujer Faquilo a la iglesia de } \\
\text { Oviedo }\end{array}$ & $\begin{array}{c}\text { Monasterio de S. Salvador } \\
\text { de Grandas (Grandas de } \\
\text { Salime })^{134}\end{array}$ & $\mathrm{LTO}^{\circ} 25$ \\
\hline $\begin{array}{l}975 \text { (refacción } \\
\text { pelagiana) }\end{array}$ & $\begin{array}{c}\text { Donación de Cromacio Mellíniz, } \\
\text { su mujer Rosilde Feles, sus hijos } \\
\text { y su hermana María Mellíniz a la } \\
\text { iglesia de Oviedo }\end{array}$ & $\begin{array}{l}\text { Monasterio de S. Jorge de } \\
\text { Villagrufe (Allande) }\end{array}$ & LTO n 24 \\
\hline 976 (original) & $\begin{array}{c}\text { Donación del conde Fruela Velaz } \\
\text { a la iglesia de Oviedo }\end{array}$ & Cartavio (Coaña) & $\begin{array}{l}\text { Orixinales } \\
n^{\circ} 23\end{array}$ \\
\hline 985 (original) & $\begin{array}{c}\text { Donación de Jimena al monasterio } \\
\text { de Sahagún }\end{array}$ & $\begin{array}{l}\text { Villa de Selorio } \\
\text { (Villaviciosa) }\end{array}$ & $\begin{array}{l}\text { Sahagún } \mathrm{n}^{\circ} \\
\quad 328\end{array}$ \\
\hline $\begin{array}{l}2^{\mathrm{a}} \text { mitad del s. } \\
\mathrm{X}^{135} \text { (noticia del } \\
\text { s. XIII) }\end{array}$ & $\begin{array}{c}\text { Donación de Oveco Sánchez } \\
\text { al monasterio de S. Miguel de } \\
\text { Bárcena }\end{array}$ & Villajulián (Tineo) & $\begin{array}{l}\text { RC p. } 169 \\
\text { (fol. 76vA8- } \\
12)\end{array}$ \\
\hline $\begin{array}{c}\text { finales s. X o } \\
\text { ppios. s. XI } \\
\text { (sucesivas } \\
\text { refacciones } \\
\text { tardías) }^{136}\end{array}$ & $\begin{array}{l}\text { Dotación fundacional del } \\
\text { monasterio de Sta. María de } \\
\text { Obona por Adelgáster }\end{array}$ & Obona (Tineo) & Obona $\mathrm{n}^{\mathrm{o}} 1$ \\
\hline $\begin{array}{l}1000 \text { (refacción } \\
\text { pelagiana) }\end{array}$ & $\begin{array}{c}\text { El traidor Analso Garvixo entrega } \\
\text { sus bienes a Alfonso V a cambio } \\
\text { de salvar la vida, y éste los dona a } \\
\text { la iglesia de Oviedo }\end{array}$ & $\begin{array}{l}\text { Las cláusulas con mención a } \\
\text { esclavos son genéricas, pero } \\
\text { el único bien mencionado es } \\
\text { la villa de Tox (Navia) }\end{array}$ & LTO n 30 \\
\hline $\begin{array}{l}1006 \text { (refacción } \\
\text { pelagiana) }\end{array}$ & $\begin{array}{c}\text { Donación de los condes Fafila } \\
\text { Espasandiz y Urraca a la iglesia } \\
\text { de Oviedo }\end{array}$ & $\begin{array}{l}\text { Monasterio de Tol } \\
\text { (Castropol) }\end{array}$ & LTO no 29 \\
\hline
\end{tabular}

134 A tenor de lo comentado en Francisco Javier Fernández Conde, El Libro de los Testamentos de la Catedral de Oviedo, ed. Iglesia Nacional Española, Roma, 1971, pp. 194-7, lo único que en este documento tan manipulado podría remitir a una donación inicial es este monasterio de S. Salvador de Grandas, no el resto de bienes de una extensa nómina que por tanto omito aquí.

135 Francisco Javier Fernández Conde, "El monasterio de San Miguel de Bárzana...”, p. 124, menciona que Oveco Sánchez era sobrino de los condes Vermudo y Fruela Velaz, fundadores del monasterio de Bárcena. Además, en Corias, pp. 168-9 (f. 76rA21-B6) aparece como contemporáneo de sus tíos (para la cronología de éstos, vid. supra nota 133), por lo que es probable que falleciese en la $2^{\mathrm{a}}$ mitad del siglo X.

136 Vid. supra nota 98. 


\begin{tabular}{|c|c|c|c|}
\hline Año & Negocio & $\begin{array}{l}\text { Localización de los } \\
\text { dependientes }\end{array}$ & Referencia \\
\hline $\begin{array}{l}1006 \text { (refacción } \\
\text { pelagiana) }\end{array}$ & $\begin{array}{c}\text { Donación de la reina Velasquita a } \\
\text { la iglesia de Oviedo }\end{array}$ & $\begin{array}{l}\text { Sin determinar. La donación } \\
\text { incluye los monasterios de } \\
\text { Sta. Cruz (Oviedo, ciudad), } \\
\text { S. Salvador de Deva (Gijón), } \\
\text { S. Juan de Aboño (Carreño) } \\
\text { y S. Martín (Salas), la villa } \\
\text { de Somió (Gijón), Trasona } \\
\text { (Corvera) y la iglesia de } \\
\text { Santiago de Aces (Candamo). } \\
\text { Aclara que dona todas } \\
\text { sus heredades y esclavos, } \\
\text { excepto Candamo, Soralas y } \\
\text { Paraias (actual Pola de Lena, } \\
\text { Lena) }{ }^{137} \text {, que había entregado } \\
\text { a Alfonso V. También en } \\
\text { estos lugares, por tanto, } \\
\text { podría haber más esclavos. }\end{array}$ & LTO n 27 \\
\hline $\begin{array}{l}1010 \text { (copia del } \\
\text { s. XIII) }\end{array}$ & $\begin{array}{c}\text { Concesión de coto al monasterio } \\
\text { de S. Miguel de Bárcena por } \\
\text { Alfonso } \mathrm{V}^{138}\end{array}$ & $\begin{array}{c}\text { Bárcena, Villatresmil y } \\
\text { posesiones desde el río Gera } \\
\text { hasta Forcallao (todo en } \\
\text { Tineo) }\end{array}$ & $\begin{array}{l}\text { RC p. } 183 \\
\text { (fol. } 83 \text { r) }\end{array}$ \\
\hline $\begin{array}{l}1011 ? \text { (refacción } \\
\text { pelagiana) }\end{array}$ & $\begin{array}{l}\text { Donación de los condes Fafila } \\
\text { Espasandiz y Urraca a la iglesia } \\
\text { de Oviedo }\end{array}$ & $\begin{array}{c}\text { Villas de Villanova } \\
\text { (Noreña) }{ }^{139} \text { y Conceyín } \\
(\text { Siero })\end{array}$ & LTO n 32 \\
\hline $\begin{array}{c}1011 \text { (refacción } \\
\text { pelagiana) }\end{array}$ & $\begin{array}{c}\text { El obispo Gudesteo y los } \\
\text { canónigos ovetenses entregan } \\
\text { de manera vitalicia a los condes } \\
\text { Gundemaro y Mumadoña el } \\
\text { monasterio de Sta. María de Tol, } \\
\text { que deberá revertir a la iglesia de } \\
\text { Oviedo a su muerte }\end{array}$ & $\begin{array}{l}\text { Monasterio de Tol y villas } \\
\text { de Vale, Lantoira, Barres } \\
\text { y Villadún, todo ello en } \\
\text { Castropol; el castillo de } \\
\text { Calambre (Tapia); así como } \\
\text { la villa de San Cipriano en } \\
\text { Galicia }\end{array}$ & $\mathrm{CCO} \mathrm{n}{ }^{\circ} 40$ \\
\hline
\end{tabular}

137 Sobre el lugar de Parayas fundaría Alfonso X la pola de Lena en 1266: Juan Ignacio Ruiz De LA Peña SolAR, Las «polas» asturianas en la Edad Media..., doc. $\mathrm{n}^{\circ} 5$.

138 Además de las criaciones, el documento hace alusión a los homines de mandatione donados, que evidentemente no son esclavos pero están evolucionando hacia situaciones de fuerte dependencia personal, como se comenta en el epígrafe 5.

139 Sin duda es la Villanova de Anara en la ribera del río Noreña de CCO1 n 33 (991), que se trata casi con total seguridad de la actual Noreña. Así la identifica M Josefa SAnz Fuentes, "Índice toponímico", Liber Testamentorum Ecclesiae Ovetensis, ed. M. Moleiro, Barcelona, 1995, p. 779, s.v. "Noreña". De hecho, LTO n 17 sitúa en ambas Anaras las iglesias de S. Martín de Anes, S. Juan de Celles, S. Pedro de Pañeda y S. Martín de la Carrera, lugares que rodean Noreña.

${ }^{140}$ Las propiedades referidas son las mismas que figuran en LTO n 29 (1006) después de la mención al monasterio y sus familiis. 


\begin{tabular}{|c|c|c|c|}
\hline Año & Negocio & $\begin{array}{c}\text { Localización de los } \\
\text { dependientes }\end{array}$ & Referencia \\
\hline $\begin{array}{l}1022 \text { (noticia } \\
\text { del s. XIII) }\end{array}$ & $\begin{array}{c}\text { Donación de Gegina, sobrina } \\
\text { del obispo Oveco y hermana del } \\
\text { obispo Vermudo, a su sobrino el } \\
\text { conde Piniolo Jiménez }\end{array}$ & $\begin{array}{l}\text { Monasterio de S. Tirso } \\
\qquad(\text { Candamo })^{141}\end{array}$ & $\begin{array}{l}\text { RC p. } 145 \\
\text { (fol. } 64 \mathrm{rB} 9- \\
16)\end{array}$ \\
\hline 1023 & $\begin{array}{c}\text { Consagración y dotación } \\
\text { fundacional de la iglesia de S. } \\
\text { Salvador de Fuentes }\end{array}$ & $\begin{array}{l}\text { Villa de Bedriñana } \\
\text { (Villaviciosa) }\end{array}$ & $\begin{array}{c}\text { Inscripciones } \\
\mathrm{n}^{\mathrm{o}} 242\end{array}$ \\
\hline $\begin{array}{l}1037 \text { (tanto el } \\
\text { diploma suelto } \\
\text { como la copia } \\
\text { en el Liber son } \\
\text { refacciones } \\
\text { pelagianas) }\end{array}$ & $\begin{array}{l}\text { La condesa Mumadoña, viuda } \\
\text { de Gundemaro Pinióliz, y su } \\
\text { hijo Fernando Gundemáriz, } \\
\text { entregan varios monasterios a } \\
\text { Gontrodo Gundemáriz, su hijastra } \\
\text { y hermana, bajo condición de } \\
\text { revertir a la iglesia de Oviedo a la } \\
\text { muerte de la receptora }\end{array}$ & $\begin{array}{c}\text { Monasterios de S. Salvador } \\
\text { de Tol (Castropol), S. Miguel } \\
\text { de Trevías (Valdés), S. } \\
\text { Martín de Besullo (Cangas } \\
\text { del Narcea) })^{142} \text { y Sta. Marina } \\
\text { (Oviedo, ciudad) }\end{array}$ & $\begin{array}{c}\mathrm{CCO} n^{\circ} 46 y \\
\operatorname{LTO~n}^{\circ} 37\end{array}$ \\
\hline $\begin{array}{l}1044 \text { (copia del } \\
\text { s. XIII) }\end{array}$ & $\begin{array}{l}\text { Dotación fundacional del } \\
\text { monasterio de Corias por los } \\
\text { condes Piniolo y Aldonza }\end{array}$ & $\begin{array}{c}\text { Monasterios de S. Martín } \\
\text { de Besullo (Cangas del } \\
\text { Narcea) }{ }^{143} \text {, S. Juan de Soto } \\
\text { de la Barca (Tineo), S. } \\
\text { Miguel de Canero (Valdés), } \\
\text { S. Antolín de Villanueva } \\
\text { (Navia), Sta. María de } \\
\text { Miudes (El Franco) y S. } \\
\text { Martín de Mántaras (Tapia), } \\
\text { así como diversas localidades } \\
\text { en los concejos de Cangas } \\
\text { del Narcea, Tineo, Allande y } \\
\text { Valdés. } \\
\end{array}$ & $\begin{array}{l}\text { RC pp. } 48-51 \\
\text { (fol. } 3 \mathrm{vB}- \\
5 \mathrm{rB})\end{array}$ \\
\hline $\begin{array}{l}\text { c. } 1044^{144} \\
\text { (noticia del s. } \\
\text { XIII) } \\
\end{array}$ & $\begin{array}{c}\text { Donación de los condes Piniolo y } \\
\text { Aldonza al monasterio de S. Juan } \\
\text { de Corias }\end{array}$ & Folgueras (Coaña) & $\begin{array}{c}\text { RC p. } 127 \\
\text { (fol. } 54 \mathrm{vA} 22- \\
23) \\
\end{array}$ \\
\hline
\end{tabular}

${ }^{141}$ Una relación de propiedades del mismo que fueron divididas en el año 1097 incluye bienes en los actuales concejos de Belmonte de Miranda, Candamo, Grado, Pravia, Salas y Tineo, con referencia a servi y ancillae: RC, pp. 145-6.

${ }^{142}$ En época bajomedieval, la parroquia de San Martín de Besullo formaba parte del arciprestazgo de Allande y no del de Cangas (Francisco Javier Fernández Conde, La Iglesia de Asturias en la Baja Edad Media. Estructuras económico-administrativas, Oviedo, Instituto de Estudios Asturianos, 1987, p. 190), pero en la actualidad está dividida entre los concejos de Allande y Cangas del Narcea. Concretamente la cabecera parroquial, el pueblo de Besullo con su iglesia de S. Martín (continuadora más que probable del emplazamiento del antiguo centro monástico citado en nuestro documento), se encuentra en el segundo.

$143 \mathrm{Vid}$. nota anterior.

${ }^{144}$ El monasterio de Miudes aparece entre los bienes incluidos en la dotación fundacional de 1044. Incluso aunque el dato fuese fruto de una interpolación tardía (sabemos que los condes conservaron parte de su patrimonio y fueron entregándolo a Corias a lo largo del abaciazgo de Arias Cromaz: Élida García García, 


\begin{tabular}{|c|c|c|c|}
\hline Año & Negocio & $\begin{array}{l}\text { Localización de los } \\
\text { dependientes }\end{array}$ & Referencia \\
\hline $\begin{array}{l}\text { c. } 1044^{145} \\
\text { (noticia del s. } \\
\text { XIII) }\end{array}$ & $\begin{array}{l}\text { Donación del conde Piniolo al } \\
\text { monasterio de S. Juan de Corias }\end{array}$ & $\begin{array}{l}\text { Villa de Almuña con sus } \\
\text { pertenencias en Luarca y } \\
\text { Portizuelo (todo en Valdés) }\end{array}$ & $\begin{array}{l}\text { RC p. } 135 \\
\text { (fol. 59rB20- } \\
\text { vA3) }\end{array}$ \\
\hline $\begin{array}{l}\text { c. } 1044^{146} \\
\text { (noticia del s. } \\
\text { XIII) }\end{array}$ & $\begin{array}{l}\text { Donación del conde Sancho, } \\
\text { hermano del conde Piniolo, al } \\
\text { monasterio de S. Juan de Corias }\end{array}$ & $\begin{array}{c}\text { Monasterio de S. Antolín } \\
\text { de Villanueva y villa de } \\
\text { Cabanella (ambos en Navia) }\end{array}$ & $\begin{array}{l}\text { RC p. } 129 \\
\text { (fol. } 56 \text { rA1- } \\
12 \text { ) }\end{array}$ \\
\hline $\begin{array}{l}\text { c. } 1044^{147} \\
\text { (noticia del s. } \\
\text { XIII) }\end{array}$ & $\begin{array}{l}\text { Donación del conde Sancho, } \\
\text { hermano del conde Piniolo, al } \\
\text { monasterio de S. Juan de Corias }\end{array}$ & Villa de Otur (Valdés) & $\begin{array}{l}\text { RC p. } 132 \\
\text { (fol. } 57 \mathrm{vA} 9- \\
12)\end{array}$ \\
\hline $\begin{array}{l}\text { c. } 1044^{148} \\
\text { (noticia del s. } \\
\text { XIII) }\end{array}$ & $\begin{array}{l}\text { Donación del conde Sancho } \\
\text { Jiménez, hermano del conde } \\
\text { Piniolo, al monasterio de Corias }\end{array}$ & $\begin{array}{l}\text { Monasterio de S. Miguel de } \\
\text { Canero (Valdés) }\end{array}$ & $\begin{array}{l}\mathrm{RC} \mathrm{p.} 135 \\
\text { (fol. 59vA18- } \\
\text { 23) }\end{array}$ \\
\hline 1045 (original) & $\begin{array}{c}\text { Carta de arras del conde }{ }^{149} \text { Fruela } \\
\text { Muñoz en favor de su esposa } \\
\text { Gontrodo }\end{array}$ & $\begin{array}{l}\text { Sin determinar. El } \\
\text { documento alude a bienes en } \\
\text { diversos lugares de Asturias } \\
\text { y León, principalmente en } \\
\text { zonas de la Cordillera. }\end{array}$ & 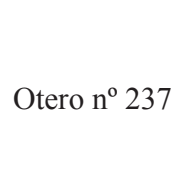 \\
\hline
\end{tabular}

San Juan Bautista de Corias..., p. 83), la fecha real de donación a Corias no podría estar muy alejada, pues el conde Piniolo parece haber fallecido en 1049, según atestiguan la inscripción de su lápida sepulcral, hoy perdida (íbid., p. 88, nota 34) y el testimonio de los Annales Castelanni Recentiores (IV, 7), ed. en José Carlos Martín Iglesias, "Los Annales Castellani Antiquiores y Annales Castellani Recentiores: edición y traducción anotada", Territorio, Sociedad y Poder, 4 (2009), p. 218.

$145 \mathrm{Vid}$. nota anterior. La villa de Almuña aparece también recogida en la dotación fundacional "cum filiis Sancie, foris illo maiore, quem ingenuamus" (RC p. 49, f. 4rB26-29).

${ }^{146}$ La referencia al conde Sancho, hermano de Piniolo, permite acotar también la datación de esta noticia, ya que el personaje aparece documentado en la primera mitad del siglo XI (Élida García García, San Juan Bautista de Corias..., p. 48) y evidentemente no pudo realizar la donación a Corias antes de la dotación fundacional de 1044. De hecho lo más probable es que formase parte de la misma, como contribución a la fundación de su hermano (ibid., p. 83), y lo cierto es que en ella - al menos en la versión que a llegado a nosotros a través del Registro, sujeta quizá a interpolaciones - ya aparece recogido el monasterio de S. Antolín de Villanueva "cum possessionibus et servis" (RC p. 49, f. 4vA3-5).

147 Vid. nota anterior. La villa de Otur aparece también recogida en la dotación fundacional "cum suis pertinenciis et servis" (RC p. 49, f. 4rB29-30).

148 Vid. nota 146. El monasterio de S. Miguel de Canero aparece también mencionado en la dotación fundacional de Corias con una relación nominal de esclavos y diversas posesiones en Valdés (RC p. 49).

149 Vid. supra nota 123. 


\begin{tabular}{|c|c|c|c|}
\hline Año & Negocio & $\begin{array}{c}\text { Localización de los } \\
\text { dependientes }\end{array}$ & Referencia \\
\hline $\begin{array}{c}1045 \text { (refacción } \\
\text { pelagiana) }\end{array}$ & $\begin{array}{l}\text { La condesa Mumadoña, viuda de } \\
\text { Gundemaro Pinioliz, dona a la } \\
\text { catedral de Oviedo el monasterio } \\
\text { de Santa María de Oviedo }\end{array}$ & $\begin{array}{l}\text { Sin determinar, aunque } \\
\text { muy probablemente en el } \\
\text { monasterio de Santa María } \\
\text { de la ciudad de Oviedo }{ }^{150}\end{array}$ & $\mathrm{CCO} \mathrm{n}^{\circ} 50^{151}$ \\
\hline 1046 (original) & $\begin{array}{c}\text { Rodrigo Sánchez paga una } \\
\text { composición al presbítero Martín } \\
\text { por haber herido a sus hombres y } \\
\text { robado su ganado }^{152}\end{array}$ & $\begin{array}{l}\text { Entorno rural de Oviedo, } \\
\text { probablemente en Roces }\end{array}$ & $\mathrm{SVO}$ n $^{\circ} 39$ \\
\hline $\begin{array}{l}1046 \text { (copia del } \\
\text { s. XIII) }{ }^{153}\end{array}$ & $\begin{array}{l}\text { Privilegio de exención concedido } \\
\text { por Fernando I a los hombres del } \\
\text { monasterio de S. Juan de Corias }\end{array}$ & $\begin{array}{c}\text { Mandación de Perpera } \\
\text { (Cangas del Narcea) y } \\
\text { posesiones del monasterio de } \\
\text { Corias en general }\end{array}$ & $\begin{array}{l}\text { RC pp. } 51-2 \\
\text { (fol. 5vA1- } \\
\text { 6rA2) }\end{array}$ \\
\hline $\begin{array}{l}1047 \text { (copia en } \\
\text { visigótica de } \\
\text { transición) }\end{array}$ & $\begin{array}{l}\text { Donación de los condes Piniolo } \\
\text { y Aldonza al monasterio de S. } \\
\text { Vicente de Oviedo }\end{array}$ & Viescas (Illas) & $\mathrm{SVO} \mathrm{n}^{\circ} 41$ \\
\hline $\begin{array}{c}1047 \text { (copia de } \\
\text { ppios. del s. XII) }\end{array}$ & $\begin{array}{c}\text { Donación de los condes Piniolo } \\
\text { y Aldonza al monasterio de S. } \\
\text { Vicente de Oviedo }\end{array}$ & Anduerga (Llanera) & $\mathrm{SVO} \mathrm{n}^{\circ} 42$ \\
\hline
\end{tabular}

${ }^{150}$ El documento fue manipulado para interpolar una extensa donación de bienes rurales muy semejante a la incluida en CCO n 46 (1012). De hecho, ésta sigue abruptamente a la entrega de bienes muebles ibidem (es decir, en el monasterio de Santa María), y ya al final del documento, inmediatamente antes de la data, se incluye también la donación de las esclavas ibidem, así que parece evidente que en el texto original quedaba más clara la localización de las mancipias en el propio cenobio.

${ }^{151}$ Una errata en CCO, con salto de línea en la mención de la localización del monasterio, debe corregirse consultando la edición de Ciríaco Miguel VigiL, Asturias monumental, epigráfica y diplomática: datos para la historia de la provincia, ed. Imprenta del Hospicio Provincial, Oviedo, 1887, vol. I, p. 72.

${ }^{152}$ El término omines es enormemente ambiguo y las fuentes lo utilizan para referirse a cualquier tipo de dependientes, pero incluyo este testimonio en la tabla porque el hecho de que la composición por heridas se pague al amo hace probable - aunque no seguro - que se trate de esclavos y no de hombres libres.

153 Doc. sospechoso: como mínimo la cláusula sobre la licencia a los servi del rey para donar 1/5 de sus bienes a Corias parece una interpolación tardía, pues no figura en otros documentos de Fernando I (por ejemplo no aparece en un "fuero" muy semejante concedido al monasterio berciano de S. Andrés de Espinareda en 1043: Espinareda $\mathrm{n}^{\circ}$ 1), con la excepción del privilegio por él otorgado a los dependientes del obispo de Oviedo, el cual nos ha llegado a través de diversas refacciones de comienzos del siglo XII (CCO n ${ }^{\circ} 45$ / LTO n 33 / Miguel Calleja Puerta, "Refacciones de un diploma de Fernando I...") y donde la cláusula es una probable innovación pelagiana (de hecho la encontramos repetida a lo largo del Liber: LTO $\mathrm{n}^{\text {os }} 10,15$, 17, 18, 20, 26 y 33). Aunque siguiendo a Francisco Javier Fernández Conde, El Libro de los Testamentos..., pp. 147-8, siempre se asume la conexión entre ambos textos a partir de la primacía del coriense, de hecho parece más probable que fuese el monasterio de Corias - no necesariamente el redactor del Registro, que bien pudo limitarse a copiar inadvertidamente una falsificación o refacción anterior- el que se inspirase en los documentos catedralicios para falsificar o reelaborar un antiguo privilegio, incorporando por ejemplo la afortunada fórmula pelagiana sobre las donaciones de los servi del rey.

${ }_{154}$ Así la considera su editor, Floriano Llorente, pero no asigna fecha a la copia. 


\begin{tabular}{|c|c|c|c|}
\hline Año & Negocio & $\begin{array}{c}\text { Localización de los } \\
\text { dependientes }\end{array}$ & Referencia \\
\hline $\begin{array}{l}1047 \text { (noticia } \\
\text { del s. XIII) }\end{array}$ & $\begin{array}{l}\text { Donación de Velasquita Peláez al } \\
\text { monasterio de S. Juan de Corias }\end{array}$ & $\begin{array}{l}\text { Villa de Quintana, en Sierra } \\
\text { (Cangas del Narcea) }\end{array}$ & $\begin{array}{l}\text { RC p. } 82 \text { (f. } \\
\text { 21rA1-5) }\end{array}$ \\
\hline 1048 (original) & $\begin{array}{c}\text { Prestimonio concedido a Contina } \\
\text { y su hija María por el monasterio } \\
\text { de S. Vicente de Oviedo }\end{array}$ & $\begin{array}{c}\text { Los hombres son ofrecidos } \\
\text { por el cenobio para trabajar } \\
\text { en la villa de la iglesia de } \\
\text { Sto. Tomás (Siero) }\end{array}$ & $\mathrm{SVO}^{\circ} 44$ \\
\hline $\begin{array}{l}1049 \text { (copia } \\
\text { en visigótica } \\
\text { redonda) })^{156}\end{array}$ & $\begin{array}{c}\text { Donación de Pelayo Vermúdez al } \\
\text { rey Fernando I }\end{array}$ & Riosa & $\begin{array}{l}\text { Eslonza } \\
\mathrm{n}^{\mathbf{o}} 37\end{array}$ \\
\hline $\begin{array}{l}1050 \text { (copia } \\
\text { pelagiana } \\
\text { sin signos de } \\
\text { intervención } \\
\text { textual } \\
\text { significativa } \\
\text { sobre el } \\
\text { original }^{157} \text { ) }\end{array}$ & $\begin{array}{c}\text { División de hombres dependientes } \\
\text { entre los monasterios de Sta. } \\
\text { María de Cartavio y S. Juan de } \\
\text { Prendonés }\end{array}$ & $\begin{array}{c}\text { Sin determinar. El } \\
\text { monasterio de Cartavio está } \\
\text { en Coaña y el de Prendonés } \\
\text { en El Franco. }\end{array}$ & LTO n 43 \\
\hline $\begin{array}{l}1^{\mathrm{a}} \text { mitad del } \\
\text { siglo XI }{ }^{158} \\
\text { (noticia del s. } \\
\text { XIII) }\end{array}$ & $\begin{array}{l}\text { Noticia de propiedad del conde } \\
\text { Piniolo }\end{array}$ & Fornellinas (Allande) & $\begin{array}{l}\text { RC p. } 98 \text { (fol } \\
\text { 33vA15) }\end{array}$ \\
\hline $\begin{array}{l}1^{\text {a }} \text { mitad del } \\
\text { siglo XI }{ }^{159} \\
\text { (noticia del s. } \\
\text { XIII) }\end{array}$ & $\begin{array}{l}\text { Donación del conde Sancho } \\
\text { Jiménez al monasterio de S. } \\
\text { Miguel de Canero }\end{array}$ & Villuir (Valdés) & $\begin{array}{l}\text { RC p. } 134 \\
\text { (fol. 58vB14- } \\
21)\end{array}$ \\
\hline $\begin{array}{l}1^{\mathrm{a}} \text { mitad del } \\
\text { siglo XI }{ }^{160} \\
\text { (noticia del s. } \\
\text { XIII) }\end{array}$ & $\begin{array}{c}\text { Población de villa por esclavos del } \\
\text { conde Sancho Jiménez }\end{array}$ & Caroyas (Valdés) & $\begin{array}{l}\text { RC p. } 135 \\
\text { (fol. 59vA4- } \\
10)\end{array}$ \\
\hline
\end{tabular}

${ }^{155}$ Parece probable que se trate de esclavos, pero no es seguro.

${ }^{156}$ Los editores señalan su condición de copia pero no dan fecha para la misma.

157 Según indica José Antonio Valdés Gallego, El Liber Testamentorum.., pp. 289-291.

${ }^{158}$ La referencia al conde Piniolo permite acotar cronológicamente la noticia, pues parece haber fallecido en 1049: Élida García García, San Juan Bautista de Corias..., p. 88, nota 34.

159 La referencia al conde Sancho Jiménez, hermano de Piniolo, permite acotar también la datación de esta noticia, ya que el personaje aparece documentado en la $1^{\text {a }}$ mitad del siglo XI: Élida García García, San Juan Bautista de Corias..., p. 48.

$160 \mathrm{Vid}$. nota anterior. 


\begin{tabular}{|c|c|c|c|}
\hline Año & Negocio & $\begin{array}{c}\text { Localización de los } \\
\text { dependientes }\end{array}$ & Referencia \\
\hline $\begin{array}{c}\text { Mediados del } \\
\text { siglo XI }{ }^{161} \\
\text { (noticia del s. } \\
\text { XIII) }\end{array}$ & $\begin{array}{c}\text { La condesa Aldonza dona esclavos } \\
\text { al monasterio de Corias, y después } \\
\text { el abad instala allí algunos más }\end{array}$ & $\begin{array}{c}\text { Forcinas (Pravia). El abad } \\
\text { Munio se trajo además dos } \\
\text { esclavos desde Ansarás } \\
\text { (Tineo). }\end{array}$ & $\begin{array}{c}\text { RC p. 143 } \\
\text { (fol. 63rA11- } \\
17)\end{array}$ \\
\hline $\begin{array}{c}\text { Meds. del s. } \\
\text { X- meds. del s. } \\
\mathrm{XI}^{162} \text { (noticia del } \\
\text { s. XIII) }\end{array}$ & $\begin{array}{c}\text { Genealogía de hombres de criazón } \\
\text { del monasterio de S. Miguel de } \\
\text { Bárcena }\end{array}$ & Pelontre (Tineo) & $\begin{array}{c}\text { RC pp. 168-9 } \\
\text { (fol. 76rA21- } \\
\text { 76vA3) }\end{array}$ \\
\hline
\end{tabular}

Fecha de recepción: 13 de octubre de 2016

Fecha de aceptación: 24 de diciembre de 2016

\footnotetext{
${ }^{161}$ La villa de Forcinas no aparece mencionada en la dotación fundacional de Corias del año 1044, pero según el Registro fue donada al cenobio por los condes Aldonza y Piniolo (RC, p. 143, f. 63rA5-10), lo que fija como fecha límite el año 1049, cuando parece haber fallecido este último: Élida García GarCía, San Juan Bautista de Corias..., p. 88, nota 34. Por su parte, la condesa Aldonza parece haber fallecido en 1063, según atestigua la inscripción de su lápida sepulcral, hoy perdida (ibid., p. 88, nota 34); y Munio ejerció el cargo de abad entre los años 1043-1062 (ibid., p. 91). Así que el conjunto de noticias aquí recogidas sobre los hombres de criazón de Forcinas debe enmarcarse dentro del período 1044-1062.

${ }^{162}$ La genealogía arranca con unos esclavos de los propios hermanos fundadores del monasterio de Bárcena, lo que remitiría a mediados del siglo X (vid. supra nota 133), y al menos en un caso se extiende durante cuatro generaciones (Menenzo - Maria - Patricio - hijos de Patricio y Gontilde), por lo que llegaría aproximadamente hasta mediados del siglo XI.
} 
